\title{
Grapevine Shoot Tip Cryopreservation and Cryotherapy: Secure Storage of Disease-Free Plants
}

\author{
Jean Carlos Bettoni ${ }^{1, *(\mathbb{D}}$, Zvjezdana Marković ${ }^{2}$, Wenlu Bi ${ }^{3}{ }^{\mathbb{D}}$, Gayle M. Volk ${ }^{4}$, Toshikazu Matsumoto ${ }^{5}$ \\ and Qiao-Chun Wang ${ }^{6}$
}

1 The New Zealand Institute for Plant and Food Research Limited, Batchelar Road, Palmerston North 4410, New Zealand

2 Department of Viticulture and Enology, Faculty of Agriculture, University of Zagreb, Svetišimunska Cesta 25, 10000 Zagreb, Croatia; zmarkovic@agr.hr

3 Department of Plant Agriculture, Gosling Research Institute for Plant Preservation, University of Guelph, Guelph, ON N1G 2W1, Canada; wenlubi@uoguelph.ca

4 USDA-ARS National Laboratory for Genetic Resources Preservation, 1111 S. Mason Street, Fort Collins, CO 80521, USA; Gayle.Volk@ars.usda.gov

5 Department of Agricultural and Forest Sciences, Faculty of Life and Environmental Science, Shimane University, 1060 Nishi-Kawatsucho, Matsue 690-8504, Japan; tmatsumoto@life.shimane-u.ac.jp

6 State Key Laboratory of Crop Stress Biology in Arid Region, College of Horticulture, Northwest A\&F University, Yangling District, Shaanxi 712100, China; qiaochunwang@nwsuaf.edu.cn

* Correspondence: Jean.Bettoni@plantandfood.co.nz

check for updates

Citation: Bettoni, J.C.; Marković, Z.; Bi, W.; Volk, G.M.; Matsumoto, T.; Wang, Q.-C. Grapevine Shoot Tip Cryopreservation and Cryotherapy: Secure Storage of Disease-Free Plants. Plants 2021, 10, 2190. https: / / doi.org/10.3390/plants10102190

Academic Editor: Marco Porceddu

Received: 17 September 2021

Accepted: 11 October 2021

Published: 15 October 2021

Publisher's Note: MDPI stays neutral with regard to jurisdictional claims in published maps and institutional affiliations.

Copyright: (c) 2021 by the authors. Licensee MDPI, Basel, Switzerland. This article is an open access article distributed under the terms and conditions of the Creative Commons Attribution (CC BY) license (https:// creativecommons.org/licenses/by/ $4.0 /)$.

\begin{abstract}
Grapevine (Vitis spp.) is one of the most economically important temperate fruit crops. Grapevine breeding programs require access to high-quality Vitis cultivars and wild species, which may be maintained within genebanks. Shoot tip cryopreservation is a valuable technique for the safe, long-term conservation of Vitis genetic resources that complements traditional field and in vitro germplasm collections. Vitis is highly susceptible to virus infections. Virus-free plants are required as propagation material for clonally propagated germplasm, and also for the global exchange of grapevine genetic resources. Shoot tip cryotherapy, a method based on cryopreservation, has proven to be effective in eradicating viruses from infected plants, including grapevine. This comprehensive review outlines/documents the advances in Vitis shoot tip cryopreservation and cryotherapy that have resulted in healthy plants with high regrowth levels across diverse Vitis species.
\end{abstract}

Keywords: cryo-banks; virus-free material; ex situ conservation; plant vitrification solution; micropropagation; Vitis

\section{Introduction}

Grapevines (Vitis spp.) are among the most important fruit crops worldwide, with plantings still expanding. Globally, the total grape-growing acreage reached about 7.4 million ha in 2019 [1]. Vitis vinifera is the major cultivated species, with about 5000 cultivars available worldwide [2,3]. An extensive grape market benefits from the continuous breeding of elite cultivars. The Vitis genus has about 80 species, and some species, such as those native to North America, Chinese wild species, and Muscadinia rotundifolia, contain valuable genes or traits that make them resistant/tolerant to abiotic and biotic stresses, and can be used for breeding elite cultivars [4-10]; for example, V. pseudoreticulata 'Baihe-35-1' (a Chinese wild species) [8], V. aestivalis 'Norton' [9], and M. rotundifolia 'Regale' [10] are highly resistant to powdery mildew caused by Erysiphe necator. Therefore, it is necessary to preserve Vitis diverse genetic resources to ensure continued access to potentially valuable traits $[6,11]$.

Grapevine breeding programs require access to high-quality Vitis cultivars and wild species, which may be maintained within genebanks. Ideally, these genebank collections 
have been characterized using molecular markers, evaluated with standardized phenotyping methods, and documented in public databases [11]. Traditionally, Vitis genebanks are maintained as whole plants in field collections and/or as stock cultures in in vitro culture [12,13]; for example, the US Department of Agriculture-Agricultural Research Service (USDA-ARS) National Clonal Germplasm Repository for Tree Fruit and Nut Crops and Grapes in Davis (CA, USA) maintains one of the most diverse Vitis collections in the world (42 taxa), where 3649 unique accessions of grapes are maintained in duplicate as vines in the field [14].

Field genebanks allow inventories to be observed throughout the year, and provide readily available plant material for use in breeding programs and propagation. However, they are expensive and high maintenance due to their intensive management requirements, and are at risk of losses from attacks by pests and diseases, and environmental disasters [15-17]. In addition to the large range of phenologies and genetic diversity, accessions also respond differently to cultural treatments, spray regimens, and pathogen/disease threats. The establishment of duplicate collections in a secondary field site is a commendable strategy to minimize the risk of loss; however, it adds to the expense of maintenance, and the collections could still be threatened by pathogens and pests $[16,17]$. In vitro genebanks provide an alternative to field collections for the short- and medium-term storage of Vitis germplasm [12,18-21]. In addition, they can be a source of clean plants for other purposes, including as source plant material for cryopreservation. However, in vitro genebanks are also labor intensive, plus they have risks of microbial contamination and genetic or somaclonal variation [22-26].

Reliable and robust back-up methods are required to augment the labor-intensive maintenance of field and in vitro collections. Cryopreservation, the storage of biological materials in liquid nitrogen $\left(\mathrm{LN},-196^{\circ} \mathrm{C}\right)$ or in its vapor phase (LNV, approx. $\left.-185^{\circ} \mathrm{C}\right)$, is now being considered as the most safe and cost-effective strategy for the long-term storage of plant genetic resources [15,27]. It complements traditional field genebanks and in vitro collections, and overcomes the above-mentioned limitations. Under cryopreserved conditions, plant material is preserved in a state whereby cellular divisions and metabolic processes are minimized, thus preserving the genetic integrity for a longer duration, without any manipulations [15,22,27-29]. Although reliable access to LN is necessary, overall, these collections require minimal space and maintenance. They also minimize the risk of biotic threats compared to field or in vitro collections [15,22].

Grapevines are genetically highly heterozygous, thus vegetative propagules, such as shoot tips and dormant buds, are the most suitable propagule source for the clonal preservation of cultivars in Vitis germplasm collections. The cryopreservation of dormant buds could be a potentially good approach, but attempts in a few Vitis species have been mostly unsuccessful [30]. Shoot tips are by far the most utilized explants for Vitis cryopreservation [16,31-37]. Shoot tips are tissues that include the apical dome (AD) and a number of leaf primordia (LP), and are able to regenerate entire plants. In some cases, as in wild species representatives of Vitis germplasm, other conservation targets, such as pollen [38,39], seeds [40], and somatic embryos [41-45], may be of interest [46,47].

Vitis is highly susceptible to virus infections. The vegetative propagation of grapevines has resulted in virus transmission from generation to generation, and virus titers have accumulated as a result of repeated propagation events [48-50]. Along with inducing increased susceptibility to other pathogens, viral diseases can cause economic losses as a result of their negative effects on yield and quality [50]. The cultivation of virus-free plants is needed to successfully control viral diseases and for the global exchange of genetic resources [51-53]. Based on cryopreservation techniques, shoot tip cryotherapy has proven to be effective in eradicating virus infections from infected plants [54-61], including grapevine [34,51,52,62-67].

Cryopreservation procedures have been established and implemented for many vegetatively propagated genebank collections $[22,29,68-74]$. Cryopreservation protocols have been described for grapevines, dating back to as early as the 1990s (Table 1); however, Vitis cryo-storage has been challenging and has not been widely used within genebanks. The re- 
cent advances in grapevine cryopreservation procedures, applicable to a wide range of Vitis species, may overcome the genotype-specific responses that have posed some of the major challenges in implementing Vitis cryopreservation procedures in genebanks [35-37,75,76]. This review provides updated and comprehensive information on the development and recent progress of Vitis shoot tip cryopreservation and cryotherapy that resulted in healthy plants with high regrowth levels across diverse Vitis species.

\section{Explant Sources}

The cryopreservation of shoot tips sourced from in vitro-grown plants is a standard procedure in many laboratories $[29,67,77]$. The source plant age, physiological state and growth phase, and quality of the in vitro stock cultures and shoot tips play significant roles in successful cryoprocedures [27,77-79].

Regardless of the explant sources, all shoot tip cryopreservation protocols use tissue culture to some extent. Therefore, the first essential step, before considering cryopreservation, is to optimize the micropropagation system, ensuring that optimal culture media formulation and growth conditions have been established to induce favorable physiological conditions for shoot tip donor plants [46,80,81].

Shoot tips excised from apical or axillary buds of in vitro-grown cultures are usually the most common explant used for the cryopreservation of vegetatively propagated species, including grapevine (Table 1; Figure 1B,C). When available, in vitro stock cultures provide a source of material for cryopreservation throughout the year, and they are easy to multiply and to manipulate [82,83]. It is preferable to introduce plants into tissue culture from actively growing shoots to establish clean in vitro stock cultures. However, the process of introducing plants into tissue culture, and the subsequent multiplication steps dramatically increase the cost, labor and time requirements of the cryopreservation procedure [46,67]. It could take a period of six to twelve months to introduce a Vitis accession into tissue culture and produce adequate amounts of culture for cryopreservation.
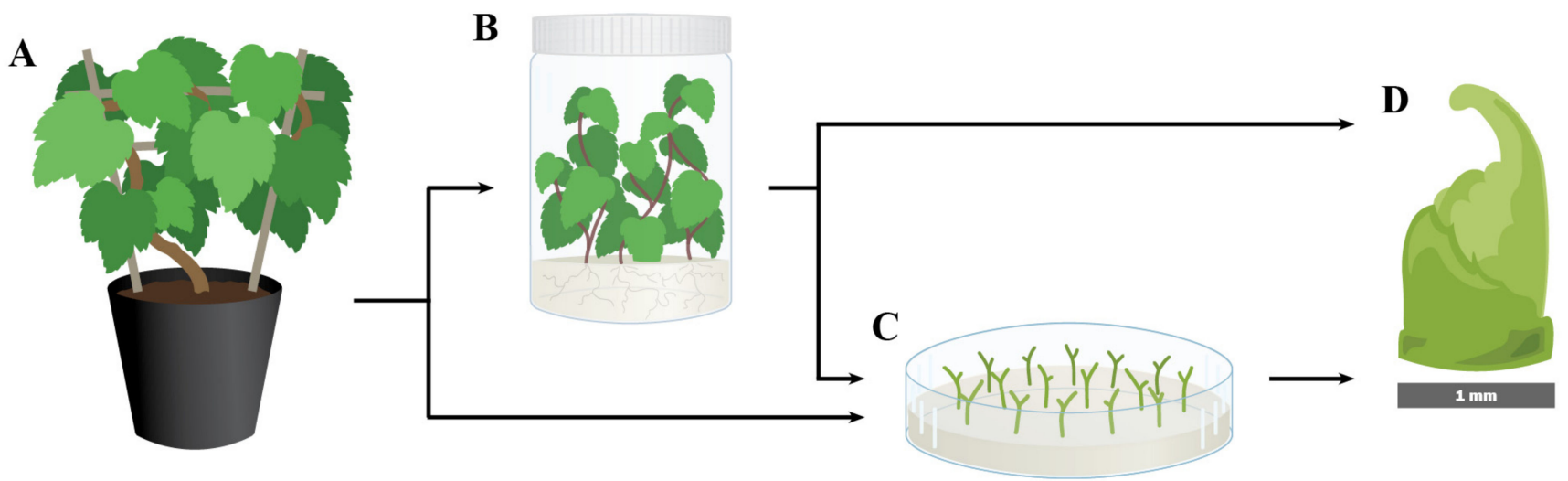

Figure 1. Production and preparation of grapevine shoot tips for cryopreservation procedures. Nodal sections (microcuttings) sourced from either greenhouse-grown plants (A) or in vitro stock cultures (B), either with or without a two-week culture in shooting medium (C,D) prior to excision of apical shoot tips (D). 
Table 1. List of research reported from 1989 to 2021 on grapevine shoot tip cryopreservation.

\begin{tabular}{|c|c|c|c|c|c|c|c|}
\hline $\begin{array}{l}\text { Species, No. } \\
\text { Genotypes Tested }\end{array}$ & Explant Source & $\begin{array}{c}\text { Cryo } \\
\text { Method }\end{array}$ & Pretreatment & Preculture & $\begin{array}{c}\text { Best Cryoprotectant/ } \\
\text { Dehydration Treatment }\end{array}$ & Regrowth (\%) & Year Ref. \\
\hline V. labrusca, 3 & $\begin{array}{l}\text { ST }(1-2 \mathrm{~mm} \text {; type } \\
\mathrm{n} / \mathrm{s}) \text { harvested from } \\
\text { greenhouse plants }\end{array}$ & TEC & None & None & $\begin{array}{l}10 \% \text { DMSO }+60 \mathrm{~g} \mathrm{~L}^{-1} \text { sucrose } \\
\left(2 \mathrm{~h} \text { at } 20{ }^{\circ} \mathrm{C}\right) \rightarrow \text { cooled } \\
\left(0.5^{\circ} \mathrm{C} \min ^{-1}\right) \text { to } \\
-20{ }^{\circ} \mathrm{C} /-30{ }^{\circ} \mathrm{C} /-40{ }^{\circ} \mathrm{C} \rightarrow \\
\mathrm{LN}\end{array}$ & $87-100 \%$ survival & $\begin{array}{l}1989 \\
{[84]}\end{array}$ \\
\hline \multirow[t]{2}{*}{ V. vinifera, 1} & \multirow[t]{2}{*}{$\begin{array}{l}\text { AxST (size } \mathrm{n} / \mathrm{s}) \\
\text { harvested from } \\
\text { in vitro cultures that } \\
\text { are } 7 \text { weeks old }\end{array}$} & $\begin{array}{l}\text { ED } \\
+ \\
\text { TEC }\end{array}$ & \multirow[t]{2}{*}{ None } & \multirow[t]{2}{*}{$\begin{array}{l}\text { Liquid MS with increased } \\
\text { sucrose concentrations every } \\
2 \mathrm{~d} \text { of } 0.3,0.5 \text { and } 0.75 \mathrm{M} \text { every } \\
2 \mathrm{~d} \text {, and then every } 1 \text { day of } 1 \text {, } \\
1.25 \text { and } 1.5 \mathrm{M} \text { (temperature } \\
\mathrm{n} / \mathrm{s} \text { ) }\end{array}$} & $\begin{array}{l}\text { Bead desiccation to } 20 \%+ \\
\text { cooled }\left(0.5^{\circ} \mathrm{C} \mathrm{min}-1\right) \text { from } \\
+20^{\circ} \mathrm{C} \text { to }-80^{\circ} \mathrm{C} \rightarrow \mathrm{LN}\end{array}$ & 24 & \multirow[t]{2}{*}{$\begin{array}{l}1991 \\
{[85]}\end{array}$} \\
\hline & & ED & & & Bead desiccation to $20 \% \rightarrow \mathrm{LN}$ & No shoot regrowth & \\
\hline \multirow[t]{2}{*}{ V. vinifera, 1} & \multirow{2}{*}{$\begin{array}{l}\text { AxST (size } \mathrm{n} / \mathrm{s}) \\
\text { harvested from } \\
\text { in vitro cultures that } \\
\text { are } 7 \text { to } 8 \text { weeks old }\end{array}$} & $\begin{array}{c}\text { ED } \\
+ \\
\text { TEC }\end{array}$ & \multirow[t]{2}{*}{ None } & \multirow{2}{*}{$\begin{array}{l}\text { Liquid MS with increased } \\
\text { sucrose concentrations every } \\
2 \text { days of } 0.3,0.5 \text { and } 0.75 \mathrm{M} \\
\text { and } 1 \mathrm{M} \text { (temperature } \mathrm{n} / \mathrm{s} \text { ) }\end{array}$} & $\begin{array}{l}\text { Bead desiccation to } 22 \%+ \\
\text { cooled }\left(0.5^{\circ} \mathrm{C} \min ^{-1}\right) \text { from }+ \\
20{ }^{\circ} \mathrm{C} \text { to }-100{ }^{\circ} \mathrm{C} \rightarrow \mathrm{LN}\end{array}$ & 30 & \multirow[t]{2}{*}{$\begin{array}{l}1993 \\
{[86]}\end{array}$} \\
\hline & & ED & & & Bead desiccation to $22 \% \rightarrow \mathrm{LN}$ & $\begin{array}{c}30 \% \\
\text { survival }\end{array}$ & \\
\hline V. vinifera, 3 & $\begin{array}{l}\text { AxST (size } \mathrm{n} / \mathrm{s} \text { ) } \\
\text { harvested from } \\
\text { in vitro cultures (age } \\
\mathrm{n} / \mathrm{s})\end{array}$ & $\begin{array}{c}\text { ED } \\
+ \\
\text { TEC }\end{array}$ & None & $\begin{array}{l}\text { Liquid MS with increased } \\
\text { sucrose concentrations every } \\
24 \text { h of } 0.3,0.6 \text { and } 1 \mathrm{M}\left(25^{\circ} \mathrm{C}\right)\end{array}$ & $\begin{array}{l}\text { Bead desiccation to } 30 \%+ \\
\text { beads cooled from } \\
0.5^{\circ} \mathrm{C} \text { min }^{-1} \text { to }-80{ }^{\circ} \mathrm{C} \rightarrow \mathrm{LN}\end{array}$ & No shoot regrowth & $\begin{array}{l}2000 \\
{[87]}\end{array}$ \\
\hline $\begin{array}{l}\text { LN33 (Vitis L.), } 1 \\
\text { V. vinifera, } 1\end{array}$ & $\begin{array}{l}\mathrm{ST}(1 \mathrm{~mm} \text {; type } \mathrm{n} / \mathrm{s}) \\
\text { harvested from } \\
\text { in vitro cultures that } \\
\text { are } 4 \text { weeks old }\end{array}$ & ED & None & $\begin{array}{l}1 / 2 \mathrm{MS} \text { with increased sucrose } \\
\text { concentrations every } 24 \mathrm{~h} \text { of } \\
0.25,0.5,0.75 \text { and } 1 \mathrm{M}+ \\
2.6 \mathrm{~g} \mathrm{~L}^{-1} \text { gellan gum }\left(24^{\circ} \mathrm{C}\right)\end{array}$ & Bead desiccation to $16 \% \rightarrow \mathrm{LN}$ & $40-60 \%$ survival & $\begin{array}{l}2000 \\
{[88]}\end{array}$ \\
\hline$V$. vinifera, 4 & $\begin{array}{l}\text { AxST }(2 \mathrm{~mm}) \\
\text { harvested from } \\
\text { in vitro cultures that } \\
\text { are } 5 \text { months old }\end{array}$ & $\begin{array}{c}\text { ED } \\
+ \\
\text { TEC }\end{array}$ & $\begin{array}{l}\text { Cold-hardening for } \\
4 \text { weeks at } 5{ }^{\circ} \mathrm{C}\end{array}$ & $\begin{array}{l}\text { B5 medium with increased } \\
\text { sucrose concentrations every } \\
24 \mathrm{~h} \text { of } 0.1,0.3,0.7 \text { and } 1 \mathrm{M}+ \\
5 \mathrm{~g} \mathrm{~L}^{-1} \text { agar }\left(5^{\circ} \mathrm{C}\right)\end{array}$ & $\begin{array}{l}\text { Bead desiccation to } 21 \%+ \\
\text { cooled }\left(0.2^{\circ} \mathrm{C} \min ^{-1}\right) \text { to } \\
-40^{\circ} \mathrm{C} \rightarrow \mathrm{LN}\end{array}$ & $15-40$ & $\begin{array}{l}2001 \\
{[89]}\end{array}$ \\
\hline
\end{tabular}


Table 1. Cont

\begin{tabular}{|c|c|c|c|c|c|c|c|}
\hline $\begin{array}{l}\text { Species, No. } \\
\text { Genotypes Tested }\end{array}$ & Explant Source & $\begin{array}{c}\text { Cryo } \\
\text { Method }\end{array}$ & Pretreatment & Preculture & $\begin{array}{c}\text { Best Cryoprotectant/ } \\
\text { Dehydration Treatment }\end{array}$ & Regrowth (\%) & Year Ref. \\
\hline \multirow[t]{2}{*}{ LN33 (Vitis L.), 1} & \multirow{2}{*}{$\begin{array}{l}\mathrm{ST}(1 \mathrm{~mm} \text {; type } \mathrm{n} / \mathrm{s}) \\
\text { harvested from } \\
\text { in vitro cultures that } \\
\text { are } 4 \text { weeks old }\end{array}$} & VI & \multirow[t]{2}{*}{ None } & $\begin{array}{l}1 / 2 \mathrm{MS} \text { with increased sucrose } \\
\text { concentrations every } 24 \mathrm{~h} \text { of } \\
0.25,0.5 \text { and } 0.75 \mathrm{M}+ \\
2.6 \mathrm{~g} \mathrm{~L}^{-1} \text { Gelrite }\left(24^{\circ} \mathrm{C}\right)\end{array}$ & $\begin{array}{l}2 \mathrm{M} \text { glycerol }+0.75 \mathrm{M} \text { sucrose } \\
\left(60 \mathrm{~min} \text { at } 25^{\circ} \mathrm{C}\right) \rightarrow 1 / 2 \text { PVS2 } \\
\left(30 \mathrm{~min} \text { at } 0^{\circ} \mathrm{C}\right) \rightarrow \mathrm{PVS} 2 \\
\left(50 \mathrm{~min} \text { at } 0^{\circ} \mathrm{C}\right) \rightarrow \mathrm{LN}\end{array}$ & $\begin{array}{c}45 \% \\
\text { survival }\end{array}$ & \multirow[t]{2}{*}{$\begin{array}{l}2003 \\
{[33]}\end{array}$} \\
\hline & & ED & & $\begin{array}{l}\text { Preculture described above }+ \\
\text { additional } 1 \mathrm{~d} \text { on } 1 \mathrm{M} \text { sucrose } \\
+2.6 \mathrm{~g} \mathrm{~L}^{-1} \text { Gelrite }\end{array}$ & $\begin{array}{l}\text { Bead desiccation by air-drying } \\
\text { for } 8 \mathrm{~h}(\text { beads moisture } \\
\text { content } \mathrm{n} / \mathrm{s}) \rightarrow \mathrm{LN}\end{array}$ & $\begin{array}{c}63 \% \\
\text { survival }\end{array}$ & \\
\hline \multirow[t]{2}{*}{$V$. vinifera, 1} & \multirow{2}{*}{$\begin{array}{l}\text { ST }(1 \mathrm{~mm} \text {; type } \mathrm{n} / \mathrm{s}) \\
\text { harvested from } \\
\text { in vitro cultures that } \\
\text { are } 4 \text { weeks old }\end{array}$} & VI & \multirow[t]{2}{*}{ None } & $\begin{array}{l}1 / 2 \mathrm{MS} \text { with increased sucrose } \\
\text { concentrations every } 24 \mathrm{~h} \text { of } \\
0.25,0.5 \text { and } 0.75 \mathrm{M}+ \\
2.6 \mathrm{~g} \mathrm{~L}^{-1} \text { Gelrite }\left(24^{\circ} \mathrm{C}\right)\end{array}$ & $\begin{array}{l}2 \mathrm{M} \text { glycerol }+0.75 \text { M sucrose } \\
\left(60 \text { min at } 25^{\circ} \mathrm{C}\right) \rightarrow 1 / 2 \text { PVS2 } \\
\left(30 \text { min at } 0^{\circ} \mathrm{C}\right) \rightarrow \text { PVS2 (50 } \\
\left.\text { min at } 0{ }^{\circ} \mathrm{C}\right) \rightarrow \mathrm{LN}\end{array}$ & $\begin{array}{c}50 \% \\
\text { survival }\end{array}$ & \multirow{2}{*}{$\begin{array}{l}2003 \\
{[64]}\end{array}$} \\
\hline & & ED & & $\begin{array}{l}\text { Preculture described above }+ \\
\text { additional } 1 \text { day on } 1 \mathrm{M} \\
\text { sucrose } \\
+2.6 \mathrm{~g} \mathrm{~L}^{-1} \text { Gelrite }\end{array}$ & $\begin{array}{l}\text { Bead desiccation by air-drying } \\
\text { for } 7 \mathrm{~h} \text { (beads moisture } \\
\text { content } \mathrm{n} / \mathrm{s}) \rightarrow \mathrm{LN}\end{array}$ & $\begin{array}{c}62 \% \\
\text { survival }\end{array}$ & \\
\hline $\begin{array}{l}V \text {. berlandieri } x V \text {. } \\
\text { riparia, } 1\end{array}$ & $\begin{array}{l}\text { AST and AxST } \\
(1-2 \mathrm{~mm}) \text { harvested } \\
\text { from in vitro cultures } \\
(\text { age } \mathrm{n} / \mathrm{s})\end{array}$ & EN-VI & $\begin{array}{l}\text { Cold-hardening for } \\
3 \text { weeks } \\
\text { at } 4{ }^{\circ} \mathrm{C}\end{array}$ & None & $\begin{array}{l}\left.\text { PVS2 (30 and } 90 \mathrm{~min} \text { at } 0{ }^{\circ} \mathrm{C}\right) \\
\rightarrow \mathrm{LN}\end{array}$ & Low (n/s) & $\begin{array}{l}2003 \\
{[90]}\end{array}$ \\
\hline $\begin{array}{l}V . \text { vinifera, } 7 ; V . \\
\text { berlandieri } \times \text { riparia, } 2 ; \\
V . \text { mourvedre } \times V . \\
\text { rupestris, } 1 ; V . \\
\text { coignetiae, } 1\end{array}$ & $\begin{array}{l}\text { AxST }(1 \mathrm{~mm}) \\
\text { harvested from } \\
\text { in vitro cultures that } \\
\text { are } 4 \text { to } 5 \text { months old }\end{array}$ & VI & None & $\begin{array}{l}1 / 2 \mathrm{MS}+0.3 \mathrm{M} \text { sucrose } \\
+2 \mathrm{~g} \mathrm{~L}^{-1} \text { gellan gum for } 3 \\
\text { days at } 25^{\circ} \mathrm{C}\end{array}$ & $\begin{array}{l}2 \mathrm{M} \text { glycerol }+0.4 \mathrm{M} \text { sucrose } \\
\left(20 \mathrm{~min} \text { at } 25^{\circ} \mathrm{C}\right) \rightarrow 1 / 2 \text { PVS2 } \\
\left(30 \mathrm{~min} \text { at } 0^{\circ} \mathrm{C}\right) \rightarrow \mathrm{PVS} 2 \\
\left(50 \mathrm{~min} \text { at } 0^{\circ} \mathrm{C}\right) \rightarrow \mathrm{LN}\end{array}$ & $30-87$ & $\begin{array}{c}2000 \\
{[31]} \\
2003[32]\end{array}$ \\
\hline V. vinifera, 4 & $\begin{array}{l}\text { AST }(2 \mathrm{~mm}) \\
\text { harvested from } \\
\text { in vitro cultures that } \\
\text { are } 50 \text { days old }\end{array}$ & $\begin{array}{c}\text { ED } \\
+ \\
\text { TEC }\end{array}$ & None & $\begin{array}{l}\text { Culture medium with } \\
\text { increased sucrose } \\
\text { concentrations every } 24 \mathrm{~h} \text { of } \\
0.5,0.70 \text { and } 1 \mathrm{M}\left(5^{\circ} \mathrm{C}\right)\end{array}$ & $\begin{array}{l}\text { Bead desiccation to } 26 \%+ \\
\text { cooled }\left(0.2^{\circ} \mathrm{C} \min ^{-1}\right) \text { from } \\
0^{\circ} \mathrm{C} \text { to }-40^{\circ} \mathrm{C} \rightarrow \mathrm{LN}\end{array}$ & $\begin{array}{c}36 \\
\text { (average) }\end{array}$ & $\begin{array}{l}2003 \\
{[91]}\end{array}$ \\
\hline $\begin{array}{l}\text { V. berlandieri } \times \\
\text { riparia, } 1\end{array}$ & $\begin{array}{l}\text { AxST }(\text { size } \mathrm{n} / \mathrm{s}) \\
\text { harvested from } \\
\text { in vitro cultures (age } \\
\mathrm{n} / \mathrm{s})\end{array}$ & VI & None & $\begin{array}{l}0.2,0.3 \text { or } 0.4 \mathrm{M} \text { sucrose } \\
\text { (duration and conditions } \mathrm{n} / \mathrm{s} \text { ) }\end{array}$ & $\begin{array}{l}2 \mathrm{M} \text { glycerol }+0.4 \mathrm{M} \text { sucrose } \\
(30 \mathrm{~min}) \rightarrow \text { PVS2 (30, } 60 \text { or } \\
90 \mathrm{~min})(\text { conditions } \mathrm{n} / \mathrm{s}) \rightarrow \\
\mathrm{LN}\end{array}$ & No shoot regrowth & $\begin{array}{l}2007 \\
{[92]}\end{array}$ \\
\hline
\end{tabular}


Table 1. Cont

\begin{tabular}{|c|c|c|c|c|c|c|c|}
\hline $\begin{array}{l}\text { Species, No. } \\
\text { Genotypes Tested }\end{array}$ & Explant Source & $\begin{array}{c}\text { Cryo } \\
\text { Method }\end{array}$ & Pretreatment & Preculture & $\begin{array}{c}\text { Best Cryoprotectant/ } \\
\text { Dehydration Treatment }\end{array}$ & Regrowth (\%) & Year Ref \\
\hline V. vinifera, 1 & $\begin{array}{l}\text { ST }(1 \mathrm{~mm} \text {; type } \mathrm{n} / \mathrm{s}) \\
\text { harvested from } \\
\text { shoots of greenhouse } \\
\text { plants }\end{array}$ & ED & None & $\begin{array}{l}\text { 3/4 MS with increased sucrose } \\
\text { concentrations every } 24 \mathrm{~h} \text { of } \\
0.25,0.5,0.75 \text { and } 1 \mathrm{M} \\
\text { (conditions } \mathrm{n} / \mathrm{s} \text { ) }\end{array}$ & $\begin{array}{l}\text { Bead desiccation by air-drying } \\
\text { for } 12 \mathrm{~h} \text { (beads moisture } \\
\text { content } \mathrm{n} / \mathrm{s}) \rightarrow \text { LN }\end{array}$ & 59 & $\begin{array}{l}2011 \\
{[63]}\end{array}$ \\
\hline V. vinifera, 1 & $\begin{array}{l}\mathrm{ST}(2-3 \mathrm{~mm} ; \text { type } \\
\mathrm{n} / \mathrm{s}) \text { harvested from } \\
\text { in vitro cultures (age } \\
\mathrm{n} / \mathrm{s})\end{array}$ & VI & None & $\begin{array}{l}\mathrm{MS}+0.3 \mathrm{M} \text { sucrose }+8 \mathrm{~g} \mathrm{~L}^{-1} \\
\text { agar for } 1 \text { day at } 24^{\circ} \mathrm{C}\end{array}$ & $\begin{array}{l}5 \%(w / v) \text { DMSO }+5 \%(w / v) \\
\text { glycerol }+5 \%(w / v) \text { sucrose } \\
\left(50 \text { min at } 0{ }^{\circ} \mathrm{C}\right) \rightarrow \text { PVS2 } \\
\left(40 \text { min at } 0{ }^{\circ} \mathrm{C}\right) \text { or MPVS2 } * * * * \\
\left(40 \text { min at } 0{ }^{\circ} \mathrm{C}\right) \rightarrow \text { LN }\end{array}$ & 47 and 55 & $\begin{array}{l}2011 \\
{[93]}\end{array}$ \\
\hline $\begin{array}{l}V \text {. berlandieri } \times V \text {. } \\
\text { riparia, } 1\end{array}$ & $\begin{array}{l}\text { AxST }(2 \pm 1 \mathrm{~mm}) \\
\text { harvested from } \\
\text { in vitro cultures (age } \\
\mathrm{n} / \mathrm{s})\end{array}$ & VI & $\begin{array}{l}\text { Cold-hardening for } \\
2 \text { weeks at } 4{ }^{\circ} \mathrm{C}\end{array}$ & $\begin{array}{l}\mathrm{MS}+0.2,0.3 \text { or } 0.4 \mathrm{M} \text { sucrose }+ \\
8 \mathrm{~g} \mathrm{~L}^{-1} \text { agar for } 2 \text { days at } 4{ }^{\circ} \mathrm{C}\end{array}$ & $\begin{array}{l}2 \mathrm{M} \text { glycerol }+0.4 \text { M sucrose } \\
\left(30 \text { min at } 4^{\circ} \mathrm{C}\right) \rightarrow \text { PVS2 (30, } \\
\left.60 \text { or } 90 \text { min at } 0{ }^{\circ} \mathrm{C}\right) \rightarrow \text { LN }\end{array}$ & No shoot regrowth & $\begin{array}{l}2012 \\
{[94]}\end{array}$ \\
\hline \multirow[t]{2}{*}{ V. vinifera, 1} & \multirow{2}{*}{$\begin{array}{l}\text { AST }(1 \mathrm{~mm}) \\
\text { harvested from the } \\
\text { lateral shoots of } \\
\text { in vitro nodal } \\
\text { sections cultured for } \\
2 \text { weeks }\end{array}$} & ED & \multirow{2}{*}{$\begin{array}{l}\text { Nodal sections on } \\
1 / 2 \mathrm{MS}+\text { Morel's }^{-1} \\
\text { vitamins } *+20 \mathrm{~g} \mathrm{~L}^{-1} \\
\text { sucrose }+1 \mu \mathrm{mol} \mathrm{ZR} \\
+7 \mathrm{~g} \mathrm{~L}^{-1} \text { agar for } 2 \\
\text { weeks at } 24^{\circ} \mathrm{C}\end{array}$} & $\begin{array}{l}\text { Liquid } 1 / 2 \mathrm{MS} \text { with increased } \\
\text { sucrose concentrations every } \\
12 \mathrm{~h} \text { of } 0.25,0.5,0.75 \text { and } 1 \mathrm{M} \\
\left(24^{\circ} \mathrm{C}\right)\end{array}$ & $\begin{array}{l}\text { Bead desiccation to } 22.3 \% \rightarrow \\
\text { LN }\end{array}$ & 37 & \multirow{2}{*}{$\begin{array}{l}2013 \\
{[95]}\end{array}$} \\
\hline & & DV & & $\begin{array}{l}\mathrm{MS}+1 \mathrm{M} \text { sucrose }+7 \mathrm{~g} \mathrm{~L}^{-1} \\
\text { agar for } 24 \mathrm{~h} \text { at } 24{ }^{\circ} \mathrm{C}\end{array}$ & $\begin{array}{l}2 \mathrm{M} \text { glycerol }+0.4 \text { M sucrose } \\
(20 \text { min at RT }) \rightarrow \text { PVS2 } \\
\left(50 \text { min at } 0{ }^{\circ} \mathrm{C}\right) \rightarrow \text { LN }\end{array}$ & 50 & \\
\hline V. vinifera, 2 & $\begin{array}{l}\text { AxST }(1 \mathrm{~mm}) \\
\text { harvested from } \\
\text { greenhouse-grown } \\
\text { plants }\end{array}$ & DV & None & $\begin{array}{l}\text { 1/2 MS + 0.3 M sucrose }+ \\
0.16 \mathrm{mM} \mathrm{GSH} \mathrm{reduced}+ \\
0.14 \mathrm{mM} \text { AsA }+2.5 \mathrm{~g} \mathrm{~L}^{-1} \\
\text { gellan gum for } 3 \text { days at } 25^{\circ} \mathrm{C}\end{array}$ & $\begin{array}{l}2 \mathrm{M} \text { glycerol }+0.4 \mathrm{M} \text { sucrose } \\
\left(20 \text { min at } 22^{\circ} \mathrm{C}\right) \rightarrow 1 / 2 \text { PVS2 } \\
\left(10-15 \text { min at } 0^{\circ} \mathrm{C}\right) \rightarrow \text { PVS2 } \\
\left(10-20 \text { min at } 0^{\circ} \mathrm{C}\right) \rightarrow \text { LN }\end{array}$ & $40-46$ & $\begin{array}{l}2013 \\
{[96]}\end{array}$ \\
\hline
\end{tabular}


Table 1. Cont.

\begin{tabular}{|c|c|c|c|c|c|c|c|}
\hline $\begin{array}{l}\text { Species, No. } \\
\text { Genotypes Tested }\end{array}$ & Explant Source & $\begin{array}{c}\text { Cryo } \\
\text { Method }\end{array}$ & Pretreatment & Preculture & $\begin{array}{c}\text { Best Cryoprotectant/ } \\
\text { Dehydration Treatment }\end{array}$ & Regrowth (\%) & Year Ref. \\
\hline \multirow[t]{2}{*}{ V. vinifera, 1} & $\begin{array}{l}\text { AST }(1 \mathrm{~mm}) \\
\text { harvested from the } \\
\text { lateral shoots of } \\
\text { in vitro nodal } \\
\text { sections cultured for } \\
2 \text { weeks }\end{array}$ & \multirow[t]{2}{*}{ DV } & $\begin{array}{l}\text { Nodal sections on } \\
1 / 2 \mathrm{MS}+\text { Morel's }^{\prime} \\
\text { vitamins } *+20 \mathrm{~g} \mathrm{~L} \mathrm{~L}^{-1} \\
\text { sucrose }+1 \mu \mathrm{mol} \mathrm{BA} \\
\text { or } \mathrm{ZR}+7 \mathrm{~g} \mathrm{~L}^{-1} \text { agar } \\
\text { for } 2 \text { weeks at } 24^{\circ} \mathrm{C}\end{array}$ & \multirow[t]{2}{*}{$\begin{array}{l}1 / 2 \mathrm{MS}+0.1 \mathrm{M} \text { sucrose }+ \\
7 \mathrm{~g} \mathrm{~L}^{-1} \text { agar for } 24 \mathrm{~h} \text { at } 25^{\circ} \mathrm{C}\end{array}$} & $\begin{array}{l}2 \mathrm{M} \text { glycerol }+0.4 \text { M sucrose } \\
(20 \text { min at RT }) \rightarrow 1 / 2 \text { PVS2 } \\
(30 \text { min at RT }) \rightarrow \text { PVS2 } \\
\left(50 \text { min at } 0{ }^{\circ} \mathrm{C}\right) \rightarrow \text { LN }\end{array}$ & 44 & \multirow[t]{2}{*}{$\begin{array}{l}2014 \\
{[97]}\end{array}$} \\
\hline & $\begin{array}{l}\text { AxST }(1 \mathrm{~mm}) \\
\text { harvested from } \\
\text { in vitro cultures that } \\
\text { are } 2 \text { months old }\end{array}$ & & None & & $\begin{array}{l}2 \mathrm{M} \text { glycerol }+0.4 \text { M sucrose } \\
(20 \text { min at } \mathrm{RT}) \rightarrow 1 / 2 \text { PVS2 } \\
(30 \text { min at RT }) \rightarrow \text { PVS2 (75 } \\
\left.\text { min at } 0{ }^{\circ} \mathrm{C}\right) \rightarrow \text { LN }\end{array}$ & 41.6 & \\
\hline V. vinifera, 1 & $\begin{array}{l}\text { AxST (size } \mathrm{n} / \mathrm{s}) \\
\text { harvested from } \\
\text { vineyard }\end{array}$ & VI & None & None & PVS2 $\left(180 \mathrm{~min}\right.$ at $\left.25^{\circ} \mathrm{C}\right) \rightarrow \mathrm{LN}$ & $\mathrm{n} / \mathrm{s}$ & $\begin{array}{l}2015 \\
{[98]}\end{array}$ \\
\hline V. vinifera, 9 & $\begin{array}{l}\text { AST }(1 \mathrm{~mm}) \\
\text { harvested from the } \\
\text { lateral shoots of } \\
\text { in vitro nodal } \\
\text { sections cultured for } \\
2 \text { weeks }\end{array}$ & DV & $\begin{array}{l}\text { Nodal sections on } \\
1 / 2 \mathrm{MS}+\text { Morel's }^{\prime} \\
\text { vitamins }+20 \mathrm{~g} \mathrm{~L} \mathrm{~L}^{-1} \\
\text { sucrose }+1 \mu \mathrm{mol} \mathrm{BA} \\
+7 \mathrm{~g} \mathrm{~L}^{-1} \text { agar for } \\
2 \text { weeks at } 24{ }^{\circ} \mathrm{C}\end{array}$ & $\begin{array}{l}1 / 2 \mathrm{MS}+0.1 \mathrm{M} \text { sucrose }+ \\
7 \mathrm{~g} \mathrm{~L}^{-1} \text { agar for } 24 \mathrm{~h} \text { at } 25^{\circ} \mathrm{C}\end{array}$ & $\begin{array}{l}2 \mathrm{M} \text { glycerol }+0.4 \mathrm{M} \text { sucrose } \\
(20 \mathrm{~min} \text { at } \mathrm{RT}) \rightarrow 1 / 2 \mathrm{PVS} 2 \\
(30 \mathrm{~min} \text { at } \mathrm{RT}) \rightarrow \mathrm{PVS} 2 \\
\left(50 \mathrm{~min} \text { at } 0{ }^{\circ} \mathrm{C}\right) \rightarrow \mathrm{LN}\end{array}$ & $0-70$ & $\begin{array}{l}2015 \\
{[34]}\end{array}$ \\
\hline \multirow{2}{*}{$\begin{array}{l}V . \text { vinifera, } 7 ; V \text {. } \\
\text { labrusca, } 1 ; V \text {.riparia, } \\
1 ; V . \text { berlandieri } \times V \text {. } \\
\text { rupestris, } 2 ; V . \\
\text { berlandieri } \times V \text {. } \\
\text { riparia, } 1\end{array}$} & \multirow{2}{*}{$\begin{array}{l}\text { AST harvest from } \\
\text { in vitro cultures (size } \\
\text { and age of cultures } \\
\mathrm{n} / \mathrm{s} \text { ) }\end{array}$} & ED & None & \multicolumn{2}{|c|}{ Following Wang et al. [32] } & $\begin{array}{c}0-9 \% \\
\text { survival }\end{array}$ & \multirow[t]{2}{*}{$\begin{array}{l}2015 \\
{[99]}\end{array}$} \\
\hline & & VI & None & \multicolumn{2}{|c|}{ Following Shatnawi et al. [83] } & $\begin{array}{c}0-1 \% \\
\text { survival }\end{array}$ & \\
\hline V. vinifera, 5 & $\begin{array}{l}\text { AST and AxST } \\
\text { harvested from } \\
\text { in vitro cultures that } \\
\text { are } 2 \text { weeks old (size } \\
\mathrm{n} / \mathrm{s} \text { ) }\end{array}$ & DV & $\begin{array}{l}\text { Cultures on } 1 / 2 \mathrm{MS}+ \\
\text { B5 vitamins }{ }^{* *}+ \\
20 \mathrm{~g} \mathrm{~L}^{-1} \text { sucrose }+ \\
0.5 \mathrm{mg} \mathrm{L}^{-1} \mathrm{BA}+ \\
0.1 \mathrm{mM} \mathrm{SA}+3 \mathrm{~g} \mathrm{~L}^{-1} \\
\text { gellan gum for } \\
2 \text { weeks at } 24^{\circ} \mathrm{C}\end{array}$ & $\begin{array}{l}1 / 2 \mathrm{MS}+\mathrm{B} 5 \text { vitamins }{ }^{* *} \text { with } \\
\text { increased sucrose } \\
\text { concentrations of } 0.25 \mathrm{M}, \\
0.5 \mathrm{M}, 0.75 \mathrm{M} \text { and } 1 \mathrm{M} \text { (every } \\
24 \mathrm{~h})+3 \mathrm{~g} \mathrm{~L}^{-1} \text { Gelrite }\left(24^{\circ} \mathrm{C}\right)\end{array}$ & $\begin{array}{l}2 \mathrm{M} \text { glycerol }+0.4 \mathrm{M} \text { sucrose } \\
(20 \mathrm{~min} \text { at } \mathrm{RT}) \rightarrow \mathrm{PVS} 2 \\
\left(36-41.5 \mathrm{~min} \text { at } 0^{\circ} \mathrm{C}\right) \rightarrow \mathrm{LN}\end{array}$ & $13-30$ & $\begin{array}{l}2015 \\
{[62]}\end{array}$ \\
\hline
\end{tabular}


Table 1. Cont.

\begin{tabular}{|c|c|c|c|c|c|c|c|}
\hline $\begin{array}{l}\text { Species, No. } \\
\text { Genotypes Tested }\end{array}$ & Explant Source & $\begin{array}{c}\text { Cryo } \\
\text { Method }\end{array}$ & Pretreatment & Preculture & $\begin{array}{c}\text { Best Cryoprotectant/ } \\
\text { Dehydration Treatment }\end{array}$ & Regrowth (\%) & Year Ref. \\
\hline V. vinifera, 3 & $\begin{array}{l}\text { AST }(1-2 \mathrm{~mm}) \\
\text { harvested from the } \\
\text { lateral shoots of } \\
\text { in vitro nodal } \\
\text { sections cultured for } \\
10 \text { days }\end{array}$ & VI & None & $\begin{array}{l}\text { Medium with increased } \\
\text { sucrose concentrations of } 0.3 \text {, } \\
0.5 \text { and } 0.75 \mathrm{M} \text { every } 24 \mathrm{~h} \\
\text { (conditions } \mathrm{n} / \mathrm{s} \text { ) }\end{array}$ & $\begin{array}{l}2 \mathrm{M} \text { glycerol }+0.4 \mathrm{M} \text { sucrose } \\
(30 \mathrm{~min} \text { at } \mathrm{RT}) \rightarrow 2 \mathrm{M} \text { glycerol } \\
+0.75 \mathrm{M} \text { sucrose }(30 \mathrm{~min} \text { at } \mathrm{RT}) \\
\rightarrow 1 / 2 \text { PVS3 }(30 \mathrm{~min} \text { at RT }) \rightarrow \\
80 \% \text { PVS3 }(60-90 \mathrm{~min})\end{array}$ & $\begin{array}{l}\mathrm{n} / \mathrm{s} \text { after } \mathrm{LN} \\
\text { exposure }\end{array}$ & $\begin{array}{l}2015 \\
{[100]}\end{array}$ \\
\hline $\begin{array}{l}V . \text { vinifera, } 4 ; V \text {. riparia } \\
\times V \text {. rupestris, } 1 ; V . \\
\text { vinifera Chasselas } \times V \text {. } \\
\text { berlandieri, } 1\end{array}$ & $\begin{array}{l}\text { AST and AxST } \\
(1-1.5 \mathrm{~mm}) \text { harvested } \\
\text { from the lateral } \\
\text { shoots of in vitro } \\
\text { nodal sections } \\
\text { cultured for } 2 \text { weeks }\end{array}$ & DV & $\begin{array}{l}\text { Nodal sections on } \\
1 / 2 \mathrm{MS}+\mathrm{B} 5 \text { vitamins } \\
* *+20 \mathrm{~g} \mathrm{~L}^{-1} \text { sucrose } \\
+0.5 \mathrm{mg} \mathrm{L} \mathrm{L}^{-1} \mathrm{BA}+ \\
0.1 \mathrm{Mm} \mathrm{SA}+3 \mathrm{~g} \mathrm{~L}^{-1} \\
\text { gellan gum for } 2 \\
\text { weeks at } 24^{\circ} \mathrm{C}\end{array}$ & $\begin{array}{l}1 / 2 \mathrm{MS}+\mathrm{B} 5 \text { vitamins }{ }^{* *} \text { with } \\
\text { increased sucrose } \\
\text { concentrations every } 24 \mathrm{~h} \text { of } \\
0.25 \mathrm{M}, 0.5 \mathrm{M}, 0.75 \mathrm{M} \text { and } 1 \mathrm{M} \\
+3 \mathrm{~g} \mathrm{~L}^{-1} \text { Gelrite }\left(24^{\circ} \mathrm{C}\right)\end{array}$ & $\begin{array}{l}2 \mathrm{M} \text { glycerol }+0.4 \mathrm{M} \text { sucrose } \\
(20 \text { min at } \mathrm{RT}) \rightarrow \text { PVS2 } \\
\left(36-43 \text { min at } 0{ }^{\circ} \mathrm{C}\right) \rightarrow \mathrm{LN}\end{array}$ & $7-45$ & $\begin{array}{l}2016 \\
{[16]}\end{array}$ \\
\hline $\begin{array}{l}\text { V. vinifera, } 6 ; \\
\text { V. pseudoreticulata, } 2\end{array}$ & \multirow{2}{*}{$\begin{array}{l}\text { AST }(1 \mathrm{~mm}) \\
\text { harvested from the } \\
\text { lateral shoots of } \\
\text { in vitro nodal } \\
\text { sections cultured for } \\
2 \text { weeks }\end{array}$} & \multirow[b]{2}{*}{ DV } & \multirow[b]{2}{*}{ None } & \multirow{2}{*}{$\begin{array}{l}1 / 2 \mathrm{MS}+0.3 \mathrm{M} \text { sucrose }+ \\
0.16 \mathrm{mM} \mathrm{GSH}+0.14 \mathrm{mM} \text { AsA } \\
+7 \mathrm{~g} \mathrm{~L}^{-1} \text { agar for } 3 \text { days at } \\
24{ }^{\circ} \mathrm{C}\end{array}$} & \multirow{2}{*}{$\begin{array}{l}2 \mathrm{M} \text { glycerol }+0.4 \mathrm{M} \text { sucrose } \\
\left(20 \mathrm{~min} \text { at } 24^{\circ} \mathrm{C}\right) \rightarrow 1 / 2 \text { PVS2 } \\
\left(30 \mathrm{~min} \text { at } 0^{\circ} \mathrm{C}\right) \rightarrow \text { PVS2 } \\
\left(50 \text { min at } 0^{\circ} \mathrm{C}\right) \rightarrow \mathrm{LN}\end{array}$} & $24-72$ & $\begin{array}{l}2018 \\
{[35]}\end{array}$ \\
\hline $\begin{array}{l}\text { V. vinifera, } 2 ; V . \\
\text { vinifera } \times \text { V. labrusca, } \\
1 ; V . p s e u d o r e t i c u l a t a, \\
1\end{array}$ & & & & & & $43-59$ & $\begin{array}{l}2018 \\
{[51]}\end{array}$ \\
\hline $\begin{array}{l}\text { V. vinifera, } 1 ; V . \\
\text { aestivalis, } 1 ; V . \\
\text { afghanistan, } 1 ; V . \\
\text { flexuosa, } 1 ; V . \text { palmate, } \\
1 ; V . \text { riparia, } 1 ; V . \\
\text { rupestris, } 1 ; V . \\
\text { sylvestris, } 1 ; V . \\
\text { treleasii, } 1\end{array}$ & $\begin{array}{l}\text { AST }(1-1.5 \mathrm{~mm}) \\
\text { harvested from the } \\
\text { lateral shoots of } \\
\text { in vitro nodal } \\
\text { sections cultured for } \\
2 \text { to } 3 \text { weeks }\end{array}$ & DV & $\begin{array}{l}\text { Nodal sections on } \\
\text { MS }+30 \mathrm{~g} \mathrm{~L}^{-1} \\
\text { sucrose }+0.2 \mathrm{mg} \mathrm{L} \mathrm{L}^{-1} \\
\mathrm{BA}+0.1 \mathrm{mMSA}+ \\
1 \mathrm{mM} \mathrm{GSH}+ \\
1 \mathrm{mM} \text { AsA }+3 \mathrm{~g} \mathrm{~L}^{-1} \\
\text { gellan gum for } \\
2-3 \text { weeks at } 25^{\circ} \mathrm{C}\end{array}$ & $\begin{array}{l}1 / 2 \mathrm{MS}+0.3 \mathrm{M} \text { sucrose }+ \\
0.1 \mathrm{mM} \mathrm{SA}+1 \mathrm{mM}^{+} \mathrm{GSH}^{* * *}+ \\
1 \mathrm{mM} \text { AsA }+3 \mathrm{~g} \mathrm{~L}^{-1} \text { gellan } \\
\text { gum for } 3 \text { days at } 25{ }^{\circ} \mathrm{C}\end{array}$ & $\begin{array}{l}2 \mathrm{M} \text { glycerol }+0.4 \mathrm{M} \text { sucrose } \\
\left(20 \mathrm{~min} \text { at } 22^{\circ} \mathrm{C}\right) \rightarrow 1 / 2 \text { PVS2 } \\
\left(30 \mathrm{~min} \text { at } 22^{\circ} \mathrm{C}\right) \rightarrow \text { PVS2 } \\
\left(90 \mathrm{~min} \text { at } 0^{\circ} \mathrm{C}\right) \rightarrow \mathrm{LN}\end{array}$ & $25-43$ & $\begin{array}{l}2018 \\
{[36]}\end{array}$ \\
\hline
\end{tabular}


Table 1. Cont

\begin{tabular}{|c|c|c|c|c|c|c|c|}
\hline $\begin{array}{l}\text { Species, No. } \\
\text { Genotypes Tested }\end{array}$ & Explant Source & $\begin{array}{c}\text { Cryo } \\
\text { Method }\end{array}$ & Pretreatment & Preculture & $\begin{array}{c}\text { Best Cryoprotectant/ } \\
\text { Dehydration Treatment }\end{array}$ & Regrowth (\%) & Year Ref. \\
\hline \multirow{2}{*}{$\begin{array}{l}\text { V. champinii } \times 1613 \\
\text { Couderc, } 1 ; V \text {. } \\
\text { berlandieri } \times V \text {. } \\
\text { riparia, } 1 ; V \text {. shampinii, } \\
1\end{array}$} & \multirow{2}{*}{$\begin{array}{l}\text { ST }(3 \mathrm{~mm} \text {; type } \mathrm{n} / \mathrm{s}) \\
\text { harvested from } \\
\text { shoots of greenhouse } \\
\text { plants }\end{array}$} & \multirow{2}{*}{ DV } & \multirow{2}{*}{ None } & $\begin{array}{l}1 / 2 \mathrm{MS}+0.3 \mathrm{M} \text { sucrose for } \\
3 \text { days at } 25^{\circ} \mathrm{C}\end{array}$ & $\begin{array}{l}2 \mathrm{M} \text { glycerol }+0.4 \mathrm{M} \text { sucrose } \\
\left(20 \text { min at } 25^{\circ} \mathrm{C}\right) \rightarrow \text { PVS2 } \\
\left(0-50 \text { min at } 0{ }^{\circ} \mathrm{C}\right) \rightarrow \text { LN }\end{array}$ & No shoot regrowth & \multirow{2}{*}{$\begin{array}{l}2019 \\
{[101]}\end{array}$} \\
\hline & & & & $\begin{array}{l}1 / 2 \mathrm{MS} \text { with increased sucrose } \\
\text { concentrations every } 24 \mathrm{~h} \text { of } \\
0.25,0.5,0.75 \text { and } 1 \mathrm{M}\left(25^{\circ} \mathrm{C}\right)\end{array}$ & $\begin{array}{l}2 \mathrm{M} \text { glycerol }+0.4 \mathrm{M} \text { sucrose } \\
\left(20 \text { min at } 25^{\circ} \mathrm{C}\right) \rightarrow \text { PVS2 } \\
\left(50 \mathrm{~min} \text { at } 0{ }^{\circ} \mathrm{C}\right) \rightarrow \text { LN }\end{array}$ & $27-47$ & \\
\hline $\begin{array}{l}V \text {. vinifera, } 2 ; V \text {. } \\
\text { berlandieri } \times V \text {. } \\
\text { riparia, } 1\end{array}$ & $\begin{array}{l}\text { AST }(1 \mathrm{~mm}) \\
\text { harvested from the } \\
\text { lateral shoots of } \\
\text { nodal sections } \\
\text { cultured for } 2 \text { weeks } \\
\text { from growth } \\
\text { chamber stock plants }\end{array}$ & DV & 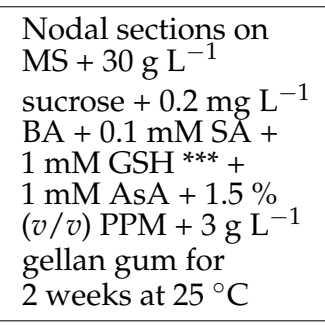 & $\begin{array}{l}1 / 2 \mathrm{MS}+0.3 \mathrm{M} \text { sucrose }+ \\
0.1 \mathrm{mM} \mathrm{SA}+1 \mathrm{mM} \mathrm{GSH} \mathrm{m}^{* * *}+ \\
1 \mathrm{mM} \text { AsA }+1.5 \%(v / v) \mathrm{PPM} \\
+3 \mathrm{~g} \mathrm{~L}^{-1} \text { gellan gum for } \\
3 \text { days at } 25^{\circ} \mathrm{C}\end{array}$ & $\begin{array}{l}2 \mathrm{M} \text { glycerol }+0.4 \mathrm{M} \text { sucrose } \\
\left(20 \mathrm{~min} \text { at } 22^{\circ} \mathrm{C}\right) \rightarrow 1 / 2 \text { PVS2 } \\
\left(30 \mathrm{~min} \text { at } 22^{\circ} \mathrm{C}\right) \rightarrow \text { PVS2 } \\
\left(30-40 \text { min at } 0^{\circ} \mathrm{C}\right) \rightarrow \text { LN }\end{array}$ & $43-64$ & $\begin{array}{l}2019 \\
{[102]}\end{array}$ \\
\hline \multirow{2}{*}{$\begin{array}{l}\text { V. vinifera, } 2 ; V . \\
\text { actinifolia, } 1 ; V . \\
\text { aestivalis, } 1 ; V . \\
\text { jacquemontii, } 1 ; V . \\
\text { flexuosa, } 1 ; V \text {. palmate, } \\
1 ; V . \text { riparia, } 1 ; V . \\
\text { rupestris, } 1 ; V . \\
\text { sylvestris, } 1 ; V . \text { ficifolia, } \\
1 ; V . \text { treleasi, } 1 ; V . \\
\text { xnovae angeliae, } 1\end{array}$} & \multirow[t]{2}{*}{$\begin{array}{l}\text { AST }(1 \mathrm{~mm}) \\
\text { harvested from the } \\
\text { lateral shoots of } \\
\text { in vitro nodal } \\
\text { sections cultured for } \\
2 \text { weeks }\end{array}$} & \multirow[t]{2}{*}{ DV } & $\begin{array}{l}\text { Nodal sections on } \\
\text { MS }+30 \mathrm{~g} \mathrm{~L}^{-1} \\
\text { sucrose }+0.2 \mathrm{mg} \mathrm{L} \mathrm{L}^{-1} \\
\mathrm{BA}+0.1 \mathrm{mMSA}+ \\
1 \mathrm{mM} \mathrm{GSH} * * * \\
1 \mathrm{mM} \text { AsA }+3 \mathrm{~g} \mathrm{~L}^{-1} \\
\text { gellan gum for } \\
2 \text { weeks at } 25^{\circ} \mathrm{C}\end{array}$ & \multirow[t]{2}{*}{$\begin{array}{l}\text { 1/2 MS }+0.3 \mathrm{M} \text { sucrose }+ \\
0.1 \mathrm{Mm} \mathrm{SA}+1 \mathrm{mM}^{+} \mathrm{GSH}^{* * *}+ \\
1 \mathrm{mM} \text { AsA }+3 \mathrm{~g} \mathrm{~L}^{-1} \text { gellan } \\
\text { gum for } 3 \text { days at } 25{ }^{\circ} \mathrm{C}\end{array}$} & $\begin{array}{l}2 \mathrm{M} \text { glycerol }+0.4 \mathrm{M} \text { sucrose } \\
\left(20 \mathrm{~min} \text { at } 22^{\circ} \mathrm{C}\right) \rightarrow 1 / 2 \text { PVS2 } \\
\left(30 \mathrm{~min} \text { at } 22^{\circ} \mathrm{C}\right) \rightarrow \text { PVS2 } \\
\left(90 \mathrm{~min} \text { at } 0^{\circ} \mathrm{C}\right) \rightarrow \text { LN }\end{array}$ & $35-72$ & \multirow[t]{2}{*}{$\begin{array}{l}2019 \\
{[37]}\end{array}$} \\
\hline & & & $\begin{array}{l}\text { Pretreatment } \\
\text { described above }+ \\
\text { cold-hardening for } \\
2 \text { weeks at } 5^{\circ} \mathrm{C}\end{array}$ & & $\begin{array}{l}2 \mathrm{M} \text { glycerol }+0.4 \text { M sucrose } \\
\left(20 \text { min at } 22^{\circ} \mathrm{C}\right) \rightarrow 1 / 2 \text { PVS2 } \\
\left(30 \mathrm{~min} \text { at } 22^{\circ} \mathrm{C}\right) \rightarrow \text { PVS2 } \\
\left(75 \text { min at } 0^{\circ} \mathrm{C}\right) \rightarrow \text { LN }\end{array}$ & $43-70$ & \\
\hline \multirow{3}{*}{$\begin{array}{l}\text { V. aestivalis, } 1 ; \\
\text { V. jacquemontii, } 1\end{array}$} & \multirow{3}{*}{$\begin{array}{l}\text { AST }(1 \mathrm{~mm}) \\
\text { harvested from the } \\
\text { lateral shoots of } \\
\text { in vitro nodal } \\
\text { sections cultured for } \\
2 \text { weeks }\end{array}$} & DV & $\begin{array}{l}\text { Nodal sections on } \\
\mathrm{MS}+30 \mathrm{~g} \mathrm{~L}^{-1}\end{array}$ & $1 / 2 \mathrm{MS}+0.3 \mathrm{M}$ sucrose + & $\begin{array}{l}2 \mathrm{M} \text { glycerol }+0.4 \mathrm{M} \text { sucrose } \\
\left(20 \mathrm{~min} \text { at } 22^{\circ} \mathrm{C}\right) \rightarrow 1 / 2 \text { PVS2 } \\
\left(30 \mathrm{~min} \text { at } 22^{\circ} \mathrm{C}\right) \rightarrow \text { PVS2 } \\
\left(90 \mathrm{~min} \text { at } 0^{\circ} \mathrm{C}\right) \rightarrow \text { LN }\end{array}$ & $53-70$ & \multirow{3}{*}{$\begin{array}{l}2019 \\
{[76]}\end{array}$} \\
\hline & & & $\begin{array}{l}\text { sucrose }+0.2 \mathrm{mg} \mathrm{L}^{-1} \\
\mathrm{BA}+0.1 \mathrm{mM} \mathrm{SA}+ \\
1 \mathrm{mM} \mathrm{GSH} \\
* * *\end{array}$ & $\begin{array}{l}0.1 \mathrm{mM} \mathrm{SA}+1 \mathrm{mM} \mathrm{GSH}^{* * *}+ \\
1 \mathrm{mM} \text { AsA }+3 \mathrm{~g} \mathrm{~L}^{-1} \text { gellan } \\
\text { gum for } 3 \text { days at } 25^{\circ} \mathrm{C}\end{array}$ & & & \\
\hline & & $\mathrm{V}-\mathrm{CP}$ & $\begin{array}{l}1 \mathrm{mM} \text { AsA }+3 \mathrm{~g} \mathrm{~L}^{-1} \\
\text { gellan gum for } 2 \\
\text { weeks at } 25^{\circ} \mathrm{C}\end{array}$ & & $\begin{array}{l}2 \mathrm{M} \text { glycerol }+0.4 \mathrm{M} \text { sucrose } \\
\left(30 \text { min at } 22^{\circ} \mathrm{C}\right) \rightarrow \text { PVS2 } \\
\left(40 \text { min at } 22^{\circ} \mathrm{C}\right) \rightarrow \text { LN }\end{array}$ & $68-70$ & \\
\hline
\end{tabular}


Table 1. Cont.

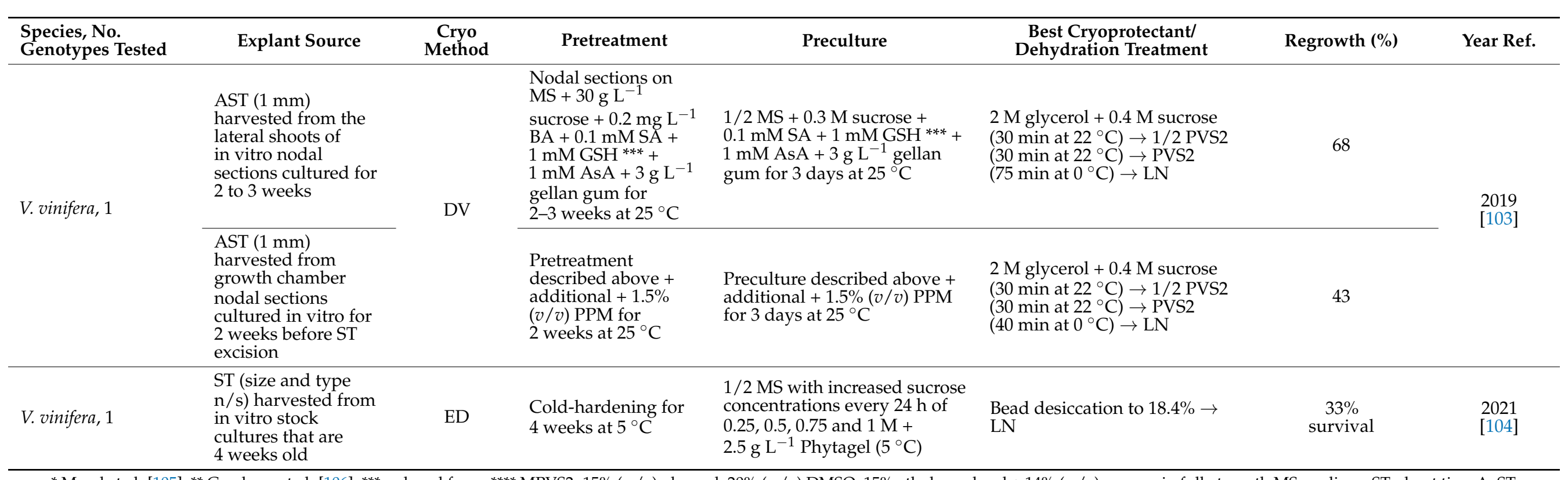

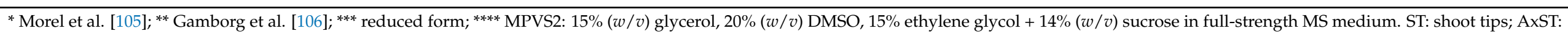

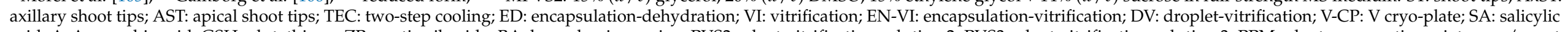

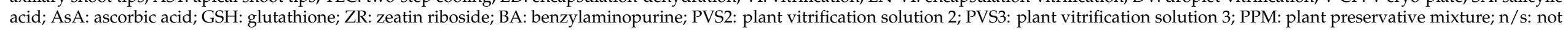
specified; RT: room temperature. 
Recently, two studies reported the cryopreservation of grapevine shoot tips that were collected directly from greenhouse-grown plants [96,102]. Hassan and Haggag [96] simplified the cryoprocedure by sampling shoot tips directly from greenhouse-grown plants, and reported regrowth percentages of $40 \%$ for $V$. vinifera 'Black Matrouh' and $47 \%$ for 'Bez El-Anza' after LN exposure. One limitation with this method is that shoot tips harvested directly from greenhouse-grown plants have non-uniform developmental stages and, thus, can exhibit highly variable responses to cryoexposure. Bettoni et al. [102] focused on improving the shoot tip quality and uniformity, plus reducing the effects of oxidation and microbial contamination by excising shoot tips from pretreated nodal sections harvested from greenhouse-grown plants (Figure 1A,C,D). With these optimized parameters, values of 43,64 and $48 \%$ shoot regrowth after LN exposure were obtained for $V$. vinifera cvs. Chardonnay and Riesling, and the rootstock selection 'Oppenheim \#4' (V. berlandieri $\times V$. riparia), respectively. Cryopreservation protocols that make use of shoot tips derived from ex vitro sourced plants require less manipulation than those from in vitro stock cultures, increasing the efficiency of cryoprocessing in genebanks by significantly reducing the laborious steps of in vitro culture establishment and multiplication. Research suggests that it may be possible to cryopreserve Vitis shoot tips without introducing each accession into tissue culture first. However, this strategy can only be applied when ex vitro materials can be easily disinfected prior to shoot tip excision [102,107].

\section{Pretreatment, Excision and Preculture of Shoot Tips}

Pretreatment, to induce tolerance to dehydration and subsequent freezing in LN, is necessary for the successful cryopreservation of shoot tips [16,35-37,97]. The optimal pretreatments of in vitro stock shoots can differ among species, and may include cold-hardening [89,108-111], exogenous application of osmotic agents, such as sorbitol, mannitol, and sugars, antioxidants, such as glutathione (GSH) and ascorbic acid (AsA) [35-37,76,108,112], polyvinylpyrrolidone [113], and/or elicitors of defense-related proteins in plants such as salicylic acid [16,36,37,75,102,103].

The recent improvements in Vitis cryopreservation are associated with improving the shoot tip quality and uniformity [95,97], pretreatment and preculture conditions, and adding antioxidants and elicitors of defense proteins in shoot tip pretreatment and preculture media [16,35-37,76,102].

Marković et al. [97] described a simple and effective step to provide uniform and actively growing shoot tips for grapevine cryopreservation protocols. Single-node microcuttings, sourced from in vitro stock cultures, were cultured for two weeks on fresh shooting medium, prior to the excision of apical shoot tips (Figure 1C). The grapevine shoot tips produced from these micro-cuttings had higher regrowth after LN exposure compared to those taken directly from in vitro plantlets. In addition, adding benzylaminopurine (BA) or zeatin riboside (ZR) in the shooting medium had a similar positive impact. Using this protocol, micro-cuttings ( $1.5 \mathrm{~cm}$ in length) of grapevine 'Portan' (V. vinifera L.) were obtained from 2-month-old in vitro plants and grown on shooting medium consisting of $1 / 2$ Murashige and Skoog medium (MS) [114], containing $20 \mathrm{~g} \mathrm{~L}^{-1}$ sucrose, $7 \mathrm{~g} \mathrm{~L}^{-1}$ agar, and $1 \mu \mathrm{mol}$ BA or ZR in Petri dishes at a density of 20 micro-cuttings per plate (Figure 1C). The plates with micro-cuttings were cultured for 2 weeks at $24 \pm 2{ }^{\circ} \mathrm{C}$, in a $12 \mathrm{~h}$ photoperiod, before uniform apical shoot tips (1 mm length; Figure 1D) were harvested and cryopreserved. In addition to higher regrowth, the shoot tips sampled from micro-cuttings cultured in shooting medium containing BA or ZR produced shoots that were more homogeneous and vigorous compared with the shoot tips sampled directly from in vitro stock plants. Shoot tips positioned at different nodes of a shoot are in varying physiological stages and, as a result, exhibit a range of sizes that differ in their response to cryogenic treatments, affecting cryopreservation results $[16,46,97]$. The use of micro-cuttings ensures the production of a large number of relatively homogeneous shoot tips, minimizes the physiological effects of apical dominance in the in vitro stock cultures, and increases the chances of a positive and uniform response to subsequent cryogenic treatments [36,97,115]. 
In recently developed protocols, micro-cuttings have been grown on a pretreatment medium supplemented with salicylic acid (SA) [16], GSH, and AsA, in addition to BA, to reduce the generation of reactive oxygen species (ROS) during cryopreservation procedures [35-37,76,102]. Pathirana et al. [16] showed that the pretreatment of donor plantlets with $0.1 \mathrm{mM}$ SA resulted in a higher level of shoot regrowth of the cryopreserved shoot tips of four V. vinifera cultivars (Sauvignon blanc, Riesling, Gewurztraminer, and Gruner Veltliner) and two rootstocks-'Millardet et de Grasset 41B' (V. vinifera Chasselas $\times$ V. berlandieri) and 'Schwarzmann' (V. riparia $\times V$. rupestris). In addition, they found that the shoot tips of rootstock 'Millardet et de Grasset 41B' could regrow following cryopreservation, albeit at a low percentage $(7 \%)$, although only when those micro-cuttings were grown on pretreatment media supplemented with SA. The inclusion of $1 \mathrm{mM}$ AsA and $1 \mathrm{mM} \mathrm{GSH}$ (reduced form) in combination with $0.2 \mathrm{mg} \cdot \mathrm{L}^{-1} \mathrm{BA}$ and $0.1 \mathrm{mM} \mathrm{SA}$ in the pretreatment medium improved the viability of cryopreserved shoot tips from a wide range of Vitis species [36,37,76,102].

For some plant species, such as kiwifruit [108], potato [109,116], and apple [110], the cold-hardening of in vitro stock cultures improved the regrowth and quality of the regenerated plants after cryopreservation. In the studies of Ganino et al. [94] and Benelli et al. [90], the shoot tips of the rootstock 'Kober $5 \mathrm{BB}^{\prime}(\mathrm{V}$. berlandieri $\times V$. riparia $)$ were harvested from in vitro stock shoots that were cold acclimated at $4{ }^{\circ} \mathrm{C}$ for 2 and 3 weeks, and cryopreserved using vitrification and encapsulation-vitrification, respectively. Regardless of the cryo-technique, they experienced nil or unsatisfactorily low levels of regrowth after cryoexposure. Bettoni et al. [37] found that the cold-hardening of in vitro shoots at $5{ }^{\circ} \mathrm{C}$ for 2 weeks did not significantly improve the regrowth of shoot tips from 12 Vitis species after cryopreservation using the droplet-vitrification technique. Nevertheless, cold-hardening may be helpful for the cryoprocessing of some untested Vitis species and/or cultivars, as shown by Zhao et al. [89] in V. vinifera cv. Cabernet Franc. They showed that the shoot tips of Cabernet Franc could be regenerated following cryopreservation by encapsulationdehydration, albeit at a low percentage (12.5\%), only when the shoot tips were harvested from 3- to 4-month-old in vitro plants that had been cold acclimated for an additional one month at $5{ }^{\circ} \mathrm{C}$.

Shoot tip size affects the success of cryopreservation-typically, shoot tips measuring 1-3 $\mathrm{mm}$ in length are most often used for cryopreservation [64,76,95]. In grapevine, $1 \mathrm{~mm}$ shoot tips were the most preferred explant and could be effectively cryopreserved, regardless of the cryoprocedures (Table 1; Figure 1D). Comparing the post-LN regrowth levels of four sizes $(0.5,1.0,1.5$ and $2.0 \mathrm{~mm})$ of Vitis shoot tips, following an encapsulationdehydration protocol, Wang et al. [64] found that $1 \mathrm{~mm}$ shoot tips produced the highest regrowth level $(65 \%)$, with larger or smaller shoot tips having lower regrowth levels. Similar results were also reported by Marković et al. [95] and Bettoni et al. [76] using a droplet-vitrification protocol.

Preculturing shoot tips is a necessary step to minimize the cell membrane injury caused by the dehydration processes, and to obtain high shoot regrowth levels in cryopreserved shoot tips [25,27,32]. Shoot tips excised from in vitro stock cultures are cultured on preculture medium with an increased osmotic potential for several hours or days, prior to cryogenic treatments. Sucrose is the most frequently used osmotic agent and has been tested for a wide range of plant genera $[46,67]$. The sucrose concentration in preculture medium typically ranges from 0.1 to $1.0 \mathrm{M}$, and can be used at either consistent or increasing concentrations over time $[16,31,36,37,81,95,104]$. The addition of antioxidants and elicitors of defense proteins to preculture media had a positive impact on the improvement of plant recovery and the quality of plantlets in cryopreserved shoot tips of grapevine [35-37,65,117]. Bi et al. [35] reported that grapevine shoot tips precultured in $1 / 2 \mathrm{MS}$ medium containing $0.3 \mathrm{M}$ sucrose for 3 days exhibited a low viability level after LN exposure. However, the inclusion of either $0.16 \mathrm{mM} \mathrm{GSH}$ or $0.14 \mathrm{mM}$ AsA to the preculture medium produced much higher recovery levels than $0.3 \mathrm{M}$ sucrose alone, with the highest recovery being in cryopreserved shoot tips precultured with a combination of sucrose, GSH, and AsA. Similar improvements in recovery levels, by adding 
$0.3 \mathrm{M}$ sucrose, $0.1 \mathrm{mM} \mathrm{SA}, 1 \mathrm{mM}$ AsA, and $1 \mathrm{mM} \mathrm{GSH}$ (reduced form) to preculture media during the cryopreservation process, have been reported by Volk et al. [36] and Bettoni et al. [37].

\section{Methods for Shoot Tip Cryopreservation}

Ezawa et al. [84] and Plessis et al. [85,86] pioneered Vitis shoot tip cryopreservation, using the classical freezing technique (two-step cooling) to cryopreserve the shoot tips of $V$. labrusca 'Campbell Early', 'Buffalo' and Delaware, and the V. vinifera cultivar Chardonnay. Advances in plant cryobiology in the 1990s, using Asparagus officinalis [118], Citrus [119], Solanum [120], and Pyrus [121], simplified effective vitrification [119] and the development of encapsulation/dehydration protocols. In these protocols, shoot tip cells are dehydrated either osmotically or physically prior to plunging them directly into LN, without the need for a programmable freezer. Vitrification and encapsulation methods result in higher freezing rates than the traditional two-step cooling technique $[27,82,122]$. Vitrification removes freezable water from cells through osmosis, following the precultured shoot tips being exposed to highly concentrated plant vitrification solution (PVS). The vitrification solution consists of a concentrated mixture of penetrating and non-penetrating cryoprotectant substances [123]. PVS2 [119] and PVS3 [124] are the most frequently used PVSs. The former consists of $30 \%(w / v)$ glycerol, $15 \%(w / v)$ ethylene glycol, $15 \%(w / v)$ dimethyl sulfoxide (DMSO), and 0.4 M sucrose in MS liquid medium [119], while the latter comprises 50\% $(w / v)$ sucrose and $50 \%(w / v)$ glycerol [124]. PVS2 has been tested on a wide range of crops [125], including grapevine (Table 1). In encapsulation/dehydration protocols, shoot tips are encapsulated in calcium alginate beads, before air drying in a laminar flow hood or in the presence of silica gel to remove water from the cells. They are usually dehydrated to a moisture content of $15-30 \%$ fresh weight basis (FWB) before LN storage [63,88,104].

Since the 1990s, there have been many reports of cryopreservation methods for grapevine, with a wide range of success levels. These methods can be classified into two-step cooling [84-87,89,91], vitrification [31-33,64,92-94,98-100], encapsulation-dehydration [33,63,64,85, $86,88,89,91,95,99,104]$, encapsulation-vitrification [90], droplet-vitrification [16,35-37,51,62,76,9597,101-103], and V cryo-plate [76] (Table 1). Some practical and useful resources on Vitis cryopreservation and cryotherapy can be found in recent review papers $[45,52,67,79,81]$, thesis documents [65,66,117], practical guides [126], and an eBook training module on Vitis shoot tip cryopreservation [127].

\subsection{Two-Step Cooling}

Ezawa et al. [84] were the first to report a two-step cooling protocol for Vitis shoot tip cryopreservation, in which the effects of the plant material being collected in different seasons, from field-grown grapevines, and pre-freezing temperatures were tested. The shoot tips (1-2 mm) harvested from field plants were surface sterilized with $70 \%$ ethanol for $30 \mathrm{~s}$, followed by $10 \%$ sodium hypochlorite solution (1\% sodium hypochlorite) and $0.1 \%$ Tween ${ }^{\circledR} 20$ for $15 \mathrm{~min}$. The shoot tips were then treated with cryoprotectant solution containing $10 \%$ DMSO and $60 \mathrm{~g} \mathrm{~L}^{-1}$ glucose at $20^{\circ} \mathrm{C}$ for $2 \mathrm{~h}$, and progressively cooled at a rate of $0.5^{\circ} \mathrm{C} \mathrm{min}-1$, from $20{ }^{\circ} \mathrm{C}$ to $-20,-30$, and $-40{ }^{\circ} \mathrm{C}$, followed by immersion in LN. The cryopreserved shoot tips were thawed in a water bath at $38^{\circ} \mathrm{C}$ and transferred to recovery medium. They found that the shoot tips collected in November and December, from Hokkaido Research Station fields in Japan, and pre-frozen to $-30{ }^{\circ} \mathrm{C}$ before $\mathrm{LN}$ immersion gave better levels of survival compared with those collected in October and pre-frozen to -20 and $-40{ }^{\circ} \mathrm{C}$, while the survival percentage of 'Buffalo' cryopreserved shoot tips was about $80 \%$, and almost all the 'Campbell Early' shoot tips only formed callus [84].

Plessis et al. [85,86] combined encapsulation-dehydration and two-step cooling to cryopreserve shoot tips from in vitro-grown plants of $V$. vinifera cultivar Chardonnay. They harvested axillary shoot tips from 7- to 8-week-old in vitro plants and encapsulated them in alginate beads, then pre-cultured them in sucrose-enriched medium ( 0.3 to $1.5 \mathrm{M}$ in Plessis et al. [85]; 0.3 to $1 \mathrm{M}$ in Plessis [86]), before conducting partial dehydration by 
air-drying for $4 \mathrm{~h}$ in the air current of a laminar flow hood (bead moisture content of $20 \% \pm 5 \%$, FWB). This was followed by cooling at a rate of $0.5{ }^{\circ} \mathrm{C} \mathrm{min}-1$, from $20{ }^{\circ} \mathrm{C}$ to $-80^{\circ} \mathrm{C}$, and then immersion in LN. The cryopreserved beads were slowly rewarmed in air at room temperature for about $15 \mathrm{~min}$. They found that encapsulation and step-wise preculturing, with increasing sucrose concentrations, eliminated the deleterious effects of direct preculturing with high sucrose concentrations [85]. With this protocol, Vitis shoot tips were successfully cryopreserved for the first time, with $24-30 \%$ recovery reported [85,86]. While this protocol was effective to cryopreserve the shoot tips of $V$. vinifera cultivar Chardonnay, Miaja et al. [87] did not report the same success in three other $V$. vinifera cultivars-Barbera, Nebbiolo, and Brachetto.

Zhao et al. [89] further improved the protocol by harvesting axillary shoot tips from 3- to 4-month-old in vitro plants that had been cold acclimated for one month at $5{ }^{\circ} \mathrm{C}$, followed by encapsulation, partial desiccation, and slow freezing. In this protocol, the cold-acclimated shoot tips were encapsulated in 3\% calcium alginate beads and precultured at $5{ }^{\circ} \mathrm{C}$ in a medium, with daily increases in the sucrose concentrations from 0.1 to $1 \mathrm{M}$, desiccated to $21 \%$ (FWB), followed by slow cooling to $-40{ }^{\circ} \mathrm{C}$ at a rate of $-0.2{ }^{\circ} \mathrm{C} \mathrm{min}-1$, before immersion in LN. With these optimized parameters, the regrowth percentages ranged between 15 and $40 \%$ for V. vinifera cvs. Cabernet Franc, Chardonnay and Fengh-51, and the rootstock LN33 hybrid (Vitis L.). Using protocols similar to that described by Zhao et al. [89], Zhai et al. [91] achieved an average of 36\% recovery after cryopreservation in four Vitis cultivars.

\subsection{Encapsulation-Dehydration}

This procedure is based on the technology developed for producing artificial seeds. As described above, Fabre and Dereuddre [120] were the first to apply the encapsulationdehydration protocol for cryopreserving Solanum shoot tips. Plessis et al. $[85,86]$ were the first to use this method to cryopreserve the shoot tips of $V$. vinifera $\mathrm{cv}$. Chardonnay. As for the two-step cooling method, the shoot tips were encapsulated, stepwise precultured with increasing sucrose concentrations $(0.3$ to $1 \mathrm{M})$, and dehydrated by air-drying in a laminar flow hood for $4 \mathrm{~h}$ (bead moisture content of $20 \% \pm 5 \%, \mathrm{FWB}$ ), prior to direct immersion in LN. The cryopreserved shoot tips were slowly rewarmed in air at room temperature for about $15 \mathrm{~min}$, and then plated onto growth medium. This procedure resulted in $30 \%$ shoot tip survival, but the regrowth levels were not specified [86].

Wang et al. [88] further improved the encapsulation-dehydration protocol by optimizing the water content of the encapsulated shoot tips, rewarming methods, and post-culture medium of the cryopreserved shoot tips. They excised shoot tips $(1 \mathrm{~mm})$ from 4-week-old in vitro cultures and encapsulated them using $3 \%$ sodium alginate solution made of $1 / 2 \mathrm{MS}$ liquid medium, and $2 \mathrm{M}$ glycerol $+0.4 \mathrm{M}$ sucrose in $0.1 \mathrm{M} \mathrm{CaCl}_{2}$ solution composed of $2 \mathrm{M}$ glycerol + $0.4 \mathrm{M}$ sucrose in liquid MS medium for $30 \mathrm{~min}$ at room temperature. The encapsulated beads ( $4 \mathrm{~mm}$ diameter), each containing one shoot tip, were then stepwise precultured with increasing sucrose concentrations of $0.25,0.5,0.75$ and $1 \mathrm{M}$, each for one day. The precultured beads were partially dehydrated in a laminar flow hood for 6 and $7.5 \mathrm{~h}$ to achieve 17.6 and $15.6 \%$ bead moisture contents for V. vinifera 'Superior' and the LN33 hybrid (Vitis L.), respectively. The beads were then transferred to cryovials and directly immersed in LN. The frozen cryovials were rapidly thawed in a water bath at $40{ }^{\circ} \mathrm{C}$ for $3 \mathrm{~min}$, and then the beads were cultured in $1 / 2 \mathrm{MS}$ medium containing $1 \mathrm{mg} \mathrm{L}^{-1}$ BA and 0.1 naphthaleneacetic acid (NAA) for 2 days in the dark, and then transferred to light conditions. With this optimized protocol, 60 and $40 \%$ shoot tip survival levels were obtained for the LN33 hybrid and cultivar 'Superior' after LN exposure, respectively. Preculturing the beads is the primary step that induces desiccation tolerance in the encapsulation-dehydration protocols, and the progressive increase in sucrose concentration avoids the deleterious effects of direct high sucrose exposure $[80,85,88,128]$. Fast thawing at $40{ }^{\circ} \mathrm{C}$, using the encapsulation-dehydration protocol, improved the survival of the cry- 
opreserved shoot tips for both the LN33 hybrid and cultivar 'Superior', compared to slow warming at room temperature for $15 \mathrm{~min}$, which was described by Plessis et al. [85,86].

The success of the encapsulation-dehydration protocol depends upon the extent of dehydration and the moisture content of the encapsulated beads of the plant material before freezing $[45,52,67,88]$. The dehydration period can vary depending on the ambient temperature, humidity, and air flow velocity, especially when air-drying in a laminar flow hood. Wang et al. [88] compared dehydration using air-drying in a laminar flow hood and silica gel, finding that the survival levels of grapevine rootstock LN33 were not dependent on the dehydration method, but, instead, on the water content of the beads. Although the two dehydration methods produced similar recovery results, the air-drying method was difficult to replicate, due to environmental variations; therefore, dehydration using silica gel was preferred $[27,45]$.

Plessis et al. $[85,86]$ reported that the highest survival $(30 \%)$ of cryopreserved shoot tips occurred when the beads encapsulating the shoot tips were partially dehydrated for $4 \mathrm{~h}$ in air, to reach a moisture content of $20 \%$. Similarly, Zhao et al. [89] showed that the encapsulated shoot tips of Cabernet Franc could be regenerated (12.5\%) from alginate beads desiccated to a moisture content of $21.8 \%$. In the study of Bayati et al. [63], $12 \mathrm{~h}$ of dehydration in air (bead moisture content not specified) resulted in 59\% shoot tip recovery in the cryopreserved beads of $V$. vinifera 'Black'. For $V$. vinifera, cv. Portan, 37\% regrowth was reported when the encapsulated shoot tips were dehydrated for $4 \mathrm{~h}$ on silica gel, to a moisture content of 22.3\% [95]. Recently, AlMousa and Hassan [104] found that the highest survival (33\%; regrowth not specified) was achieved when precultured beads were dehydrated by air-drying in a laminar flow hood for $6 \mathrm{~h}$, to a moisture content of $18.4 \%$. These results indicate that the optimal water content for the recovery of encapsulated shoots is not only species specific, but also cultivar specific. Thus, in order to achieve higher regrowth levels after LN exposure, it is necessary to test the effect of dehydration on recovery, to identify the minimum water level that the shoot tips can survive in, even without LN exposure [52,88].

Encapsulation-dehydration methods overcome some of the problems associated with the sensitivity of some plant material to vitrification solutions, because sucrose is the only osmotic agent that induces desiccation $[77,82,129]$. However, for most of the grapevine studies listed in Table 1, vitrification methods produced higher levels of shoot tip recovery than encapsulation-dehydration methods.

\subsection{Vitrification}

Vitrification-based cryopreservation is the most widely applied method for cryopreserving plant shoot tips $[68,69]$. The key to success when using this method is to induce shoot tip dehydration tolerance with highly concentrated vitrification solutions, to avoid ice crystal formation during freezing and warming $[68,80,130]$. The optimal exposure duration and temperature of vitrification solutions need to be determined to produce a high level of shoot recovery after vitrification. The optimal exposure duration depends upon the plant species, explant conditions, cryoprotectant exposure temperature, as well as preculture/pretreatment conditions [46,83,130-132].

For vitrification, pre-cultured shoot tips are treated with a loading solution (LS) composed of $2 \mathrm{M}$ glycerol + 0.4 M sucrose [133], and then exposed to PVS. The loading treatment alleviates the osmotic stress or chemical toxicity imposed by the direct exposure to PVS [133]. The explants are transferred to cryovials containing small volumes (1-1.5 mL) of fresh vitrification solution, and plunged into LN. The cryovials are then rapidly thawed in a water bath at $40{ }^{\circ} \mathrm{C}$, and the shoot tips are placed into unloading solution (ULS; $1.2 \mathrm{M}$ sucrose) to remove the cryoprotectants before being cultured in recovery medium [31].

Matsumoto et al. [31] were the first to report a vitrification cryopreservation method for four cultivars of in vitro-cultured grape shoot tips, and this protocol was further extended to 10 Vitis accessions (Figure 2(B1,B2)) [32]. In this latter study [32], they excised axillary shoot tips (1 mm long) from 4- and 5-month-old in vitro stock plants and pre-cultured 
them on solidified $1 / 2 \mathrm{MS}$ containing $0.3 \mathrm{M}$ sucrose for 3 days at $25^{\circ} \mathrm{C}$ (Figure 2A), then osmoprotected them with loading solution ( $2 \mathrm{M}$ glycerol + 0.4 M sucrose in MS medium) for $20 \mathrm{~min}$ at $25^{\circ} \mathrm{C}$ (Figure 2(B1,B2)). The shoot tips were subsequently dehydrated with a 50\% (half-strength) PVS2 for $30 \mathrm{~min}$ at $0{ }^{\circ} \mathrm{C}$, followed by full-strength PVS2 for $50 \mathrm{~min}$ at $0{ }^{\circ} \mathrm{C}$. The shoot tips were then placed in cryovials containing $1 \mathrm{~mL}$ of fresh PVS2 and directly plunged into LN (Figure $2 \mathrm{~B}$ ). The cryovials were rapidly warmed in water at $40{ }^{\circ} \mathrm{C}$ for $1 \mathrm{~min}$, and PVS2 was drained and replaced with ULS (1.2 M glycerol in MS medium), followed by incubation for $20 \mathrm{~min}$. The shoot tips were then transferred onto sterilized filter paper discs over a recovery medium $\left(1 / 2 \mathrm{MS}\right.$ medium containing $1 \mathrm{mg} \mathrm{L}^{-1}$ BA, $3 \%$ sucrose, and $0.2 \%$ gellan gum) for one day, before being transferred to fresh paper discs. This modified vitrification protocol (two-step vitrification) gave an average of $64 \%$ post-cryopreservation recovery [32], which was a much higher recovery than the conventional one-step vitrification method [31,32]. By preculturing shoot tips with increasing sucrose concentrations of $0.25,0.5$, and $0.75 \mathrm{M}$ for 3 days, each for one day, and fast thawing, Wang et al. [33] obtained about $40 \%$ shoot regrowth for the LN rootstock and scion 'Superior'.

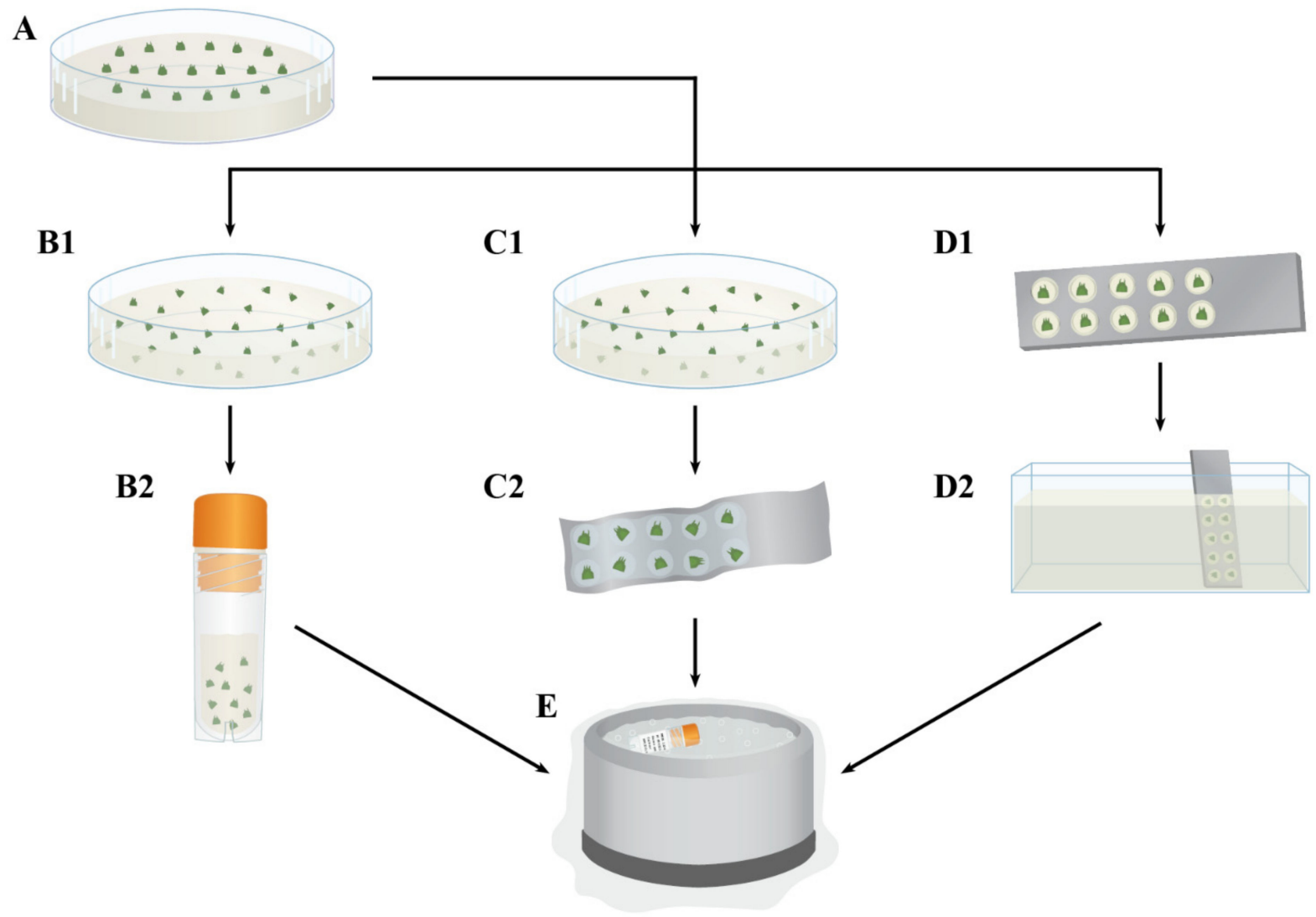

Figure 2. Major steps of grapevine shoot tip cryopreservation by vitrification (B1,B2; [31,32]), droplet-vitrification (C1,C2; [35-37]) and V cryo-plate (D1,D2; [76]). Shoot tips incubated in the preculture medium (A), osmoprotected in loading solution (B1,C1) or first attached to cryo-plates using calcium alginate solution (D1) after which cryo-plates with shoot tips attached are osmoprotected in loading solution (D2). Osmoprotected shoot tips either attached to cryo-plate (V cryo-plate) or not (vitrification and dropletvitrification) are dehydrated in PVS2 (D2; V cryo-plate). Shoot tips are transferred to cryovials containing a small volume (1-1.5 mL) of fresh vitrification solution (B2; vitrification) or a thin layer of PVS2 placed on sterile aluminum foil strips (C2; droplet-vitrification) or cryo-plates followed by liquid nitrogen exposure (E).

Using a classic one-step vitrification protocol, Fabbri et al. [92] and Ganino et al. [94] found that, for the rootstock 'Kober $5 \mathrm{BB}^{\prime}(V$. berlandieri $\times V$. riparia), the shoot tips excised from in vitro stock shoots, either with or without cold acclimation, had low survival 
using a vitrification cryoprocedure. Unlike $V$. vinifera [31], they reported no shoot tip regrowth post-cryopreservation, even though the cryopreserved shoot tips showed signs of survival $[92,94]$.

Shoot tips from V. vinifera 'Salty Kodari' were also cryopreserved using alternative loading and vitrification solutions, followed by one-step vitrification [93]. Shatnawi et al. [93] proposed an alternative to traditional LS ( $2 \mathrm{M}$ glycerol $+0.4 \mathrm{M}$ sucrose) and PVS2, in which pre-cultured shoot tips (MS + 0.3 M sucrose for 1 day) were treated with MS containing $5 \%(w / v)$ DMSO, $5 \%(w / v)$ glycerol, and $5 \%(w / v)$ sucrose for $20 \mathrm{~min}$ at $0{ }^{\circ} \mathrm{C}$, followed by either PVS2 or MPVS2 $(15 \%(w / v)$ glycerol, $20 \%(w / v)$ DMSO, $15 \%$ ethylene glycol $+14 \%$ $(w / v)$ sucrose in MS liquid medium) exposure, before immersion in LN. Between $47 \%$ and $55 \%$ shoot regrowth was achieved in shoot tips treated with PVS2 or MPVS2 for $40 \mathrm{~min}$ at $0{ }^{\circ} \mathrm{C}$, respectively. Whilst this protocol was effective for cryopreserving one accession of $V$. vinifera, Dal Bosco et al. [99] did not experience the same success with another 12 Vitis accessions, including seven $V$. vinifera cultivars, after LN exposure. Additional studies using these alternative solutions are required to validate this protocol.

\subsection{Encapsulation-Vitrification}

The encapsulation-vitrification method combines encapsulation-dehydration and vitrification procedures; encapsulated shoot tips are osmoprotected by LS and exposed to PVS2, prior to direct immersion in $\operatorname{LN}[27,52,130,134]$. This method was designed by Matsumoto and his colleagues to process a large number of explants, combining the advantages of the easy manipulation of encapsulated explants and fast dehydration by vitrification $[125,128,130,135-137]$. This method is less well studied than other cryoprocedures for grapevine (Table 1). Benelli et al. [90] investigated the efficiency of the encapsulationvitrification method on cryopreserve shoot tips from rootstock 'Kober 5BB', which was previously shown, by Ganino et al. [94], to be difficult to cryopreserve by vitrification. Benelli et al. [90] excised apical and axillary shoot tips (1-2 $\mathrm{mm})$ from in vitro cultures that had been cold acclimated for 3 weeks at $4{ }^{\circ} \mathrm{C}$ and then encapsulated in $3 \%$ calcium alginate beads. The beads were transferred to cryovials and incubated in PVS2 at $0{ }^{\circ} \mathrm{C}$ for 30 or 90 min before immersion in LN. The cryovials that had been immersed in LN were rapidly thawed in a water bath at $40^{\circ} \mathrm{C}$, and then beads were cultured in recovery medium. Shoot tips of rootstock 'Kober 5BB' could be regenerated following encapsulation-vitrification cryopreservation, albeit at unsatisfactorily low percentages (regrowth level not specified by the authors).

\subsection{Droplet-Vitrification}

Droplet vitrification is derived from the DMSO droplet methods developed by Kartha et al. [138] and Schäfer-Menuhr et al. [139-141] for freezing cassava and potato shoot tips, respectively. Initially, Kartha et al. [138] cryopreserved cassava shoot tips in droplets of cryoprotectant solution (15\% DMSO + 3\% sucrose, 15 min at room temperature) on aluminum foil strips using slow cooling. Schäfer-Menuhr et al. [139-141] further modified this protocol by cryoprotecting potato shoot tips in 10\% DMSO, for $2 \mathrm{~h}$ at room temperature, and placing them onto a droplet of cryoprotectant solution on foil strips, before plunging them directly into LN. The methods proposed by Kartha et al. [138] and Schäfer-Menuhr et al. [139-141] have not been widely used. Panis et al. [142] reported a droplet-vitrification protocol for the cryopreservation of banana shoot tips, adding the LS step and PVS2 as a vitrificant agent. This method is applicable to a wide range of genotypes and appears to have overcome the genotype specificity problem, which was a bottleneck for the wider application of plant cryopreservation. Droplet-vitrification has been successfully applied to many important plant species and is widely used in genebanks for cryopreserving vegetatively propagated crop collections $[22,68,135,143]$.

Droplet-vitrification makes use of ultra-fast shoot tip cooling and warming rates, an important requirement for successful cryopreservation protocols based on vitrification [142] High cooling rates are achieved by placing shoot tips onto droplets (1-5 $\mu \mathrm{L}$ per shoot tip) 
of cryoprotective solution on aluminum foil, with direct exposure to LN, compared to traditional vitrification methods, where shoot tips are cryopreserved within capped vials, with the cryoprotective medium $(0.5-1.5 \mathrm{~mL})$ in the vial $[46,130,142-146]$.

The droplet-vitrification method is frequently used for grapevine germplasm and has been demonstrated to be the most effective cryopreservation method across diverse Vitis species (Table 1). Marković et al. $[95,97]$ were the first to successfully apply dropletvitrification to the shoot tip cryopreservation of grapevine 'Portan' (V. vinifera L.). Briefly, in their study, micro-cuttings grown for 2 weeks on shooting medium $(1 / 2 \mathrm{MS}$ containing $20 \mathrm{~g} \mathrm{~L}^{-1}$ sucrose, $7 \mathrm{~g} \mathrm{~L}^{-1}$ agar, and $1 \mu \mathrm{mol} \mathrm{BA}$ or $\mathrm{ZR}$ ) served as source material for uniform apical shoot tips $(1 \mathrm{~mm})$ for cryopreservation. The shoot tips were precultured in MS supplemented with sucrose, either fixed ( $0.1 \mathrm{M}$ for $24 \mathrm{~h} \mathrm{[95])} \mathrm{or} \mathrm{increased} \mathrm{in} \mathrm{increments}$ (every $12 \mathrm{~h}$ of $0.25 \mathrm{M}, 0.5 \mathrm{M}, 0.75 \mathrm{M}$, and $1 \mathrm{M}$ [97]), and then treated with LS (2 M glycerol + $0.4 \mathrm{M}$ sucrose in MS medium) for $20 \mathrm{~min}$ at room temperature. Osmoprotected shoot tips were exposed either directly to full-strength PVS2 for $50 \mathrm{~min}$ at $0{ }^{\circ} \mathrm{C}$ [95], or halfstrength PVS2 for $30 \mathrm{~min}$ at room temperature and then full-strength PVS2 for $50 \mathrm{~min}$ at $0{ }^{\circ} \mathrm{C}$ [97]. PVS2-treated shoot tips were transferred to $5 \mu \mathrm{L}$ of PVS2 droplets, placed on sterile aluminum foil strips, and directly immersed in LN. For warming, the aluminum foils containing the shoot tips were immersed, for $20 \mathrm{~min}$, in ULS (1.2 M sucrose in MS medium) at room temperature, and transferred to recovery medium. Similar regrowth levels were observed in the cryopreserved shoot tip of grapevine cultivar 'Portan' exposed either directly to full-strength PVS2 (50\%), or half-strength PVS2 and then full-strength PVS2 (44\%) (two-step vitrification) prior to LN exposure.

Marković et al. [34] subsequently applied the optimized droplet-vitrification protocol [95], using the two-step vitrification method, to nine $V$. vinifera accessions, and reported that shoot tip regrowth ranged from 0 to $70 \%$, indicating a genotype-specific response to the protocol tested. Grapevines Merlot (70\%), 'Portan' (50\%), Cabernet Sauvignon (46.6\%), and Chardonnay (30\%) had acceptable levels of regrowth compared to Maraština (11\%) and four $V$. vinifera cultivars, Pošip, Škrlet, Pinot noir, and Plavac mali, that did not exhibit any shoot tip regrowth after $\mathrm{LN}$.

Pathirana et al. $[16,62]$ further optimized the droplet-vitrification protocol by excising shoot tips from micro-cuttings grown in shooting medium (pretreatment) supplemented with $0.1 \mathrm{mM} \mathrm{SA}$, followed by serial dehydration in sucrose-enriched medium of $0.25,0.5$, 0.75 and $1 \mathrm{M}$ (each for $24 \mathrm{~h}$ ), and adding a post-thaw culture medium enriched with sucrose (one day per step). Pre-cultured shoot tips (1-1.5 mm) were treated in LS (2 M glycerol + 0.4 M sucrose in MS medium; Figure 2(C1)) and then were immersed in PVS2 (one-step vitrification) for $36-43 \mathrm{~min}$ at $0{ }^{\circ} \mathrm{C}$. PVS2-treated shoot tips were placed onto droplets of PVS2 on foil strips (Figure 2(C2)) and plunged into LN (Figure 2E). For thawing, the aluminum foil strips containing the shoot tips were placed in ULS (1.2 M sucrose in MS medium) at room temperature for $20 \mathrm{~min}$ and incubated in post-thaw culture medium enriched with $0.6 \mathrm{M}$ sucrose for $24 \mathrm{~h}$, before being transferred to recovery medium in darkness for 1 week, followed by a transfer to light conditions. This cryoprotocol resulted in $7-45 \%$ shoot regrowth for 10 Vitis accessions $[16,62]$. They found a strong genotype effect with 6 of the 10 accessions tested, which had regrowth levels below $30 \%$, with rootstock 'Millardet et de Grasset 41B' showing the least regrowth potential (7\%).

Recent reports suggest that droplet-vitrification procedures show promise in overcoming genotype-specific responses in Vitis species, allowing the first efforts for the implementation of cryopreserved Vitis genebank collections to be initiated [35-37].

Bi et al. $[35,51]$ described a successful droplet-vitrification protocol that was applied to eight Vitis accessions (six V. vinifera genotypes and two V. pseudoreticulata genotypes). The procedure involved the excision of shoot tips from micro-cuttings, incubation for 3 days in preculture medium containing $0.3 \mathrm{M}$ sucrose, $0.16 \mathrm{mM} \mathrm{GSH}$, and $0.14 \mathrm{mM}$ AsA, treatment of the pre-cultured shoot tips for $20 \mathrm{~min}$ at room temperature with LS ( $2 \mathrm{M}$ glycerol $+0.4 \mathrm{M}$ sucrose in MS medium), and exposure to two-step vitrification on PVS2 (half-strength PVS2 for $30 \mathrm{~min}$, followed by full-strength PVS2 for $50 \mathrm{~min}$ at $0^{\circ} \mathrm{C}$ ). Then, the PVS2-treated shoot 
tips were transferred into $2.5 \mu \mathrm{L}$ PVS2 carried on aluminum foil, prior to direct immersion in LN. The cryopreserved shoot tips were thawed in ULS (1.2 M sucrose in MS medium) at $24^{\circ} \mathrm{C}$ for $20 \mathrm{~min}$, and post-cultured on $1 / 2 \mathrm{MS}$ supplemented with $0.6 \mathrm{M}$ sucrose and $7 \mathrm{~g} \mathrm{~L}^{-1}$ agar for $1 \mathrm{~d}$ in the dark, before being transferred to recovery medium in light conditions. With this method, the shoot tip regrowth levels ranged from 24 to $72 \%$ and averaged at $50.5 \%$ across the eight Vitis accessions.

More recently, Volk et al. [36] outlined a droplet-vitrification protocol for Vitis species through improved shoot tip quality, pretreatment and preculture conditions, vitrification exposure duration, and regrowth medium, to achieve consistent regrowth after cryopreservation. This protocol combines multiple pretreatments, many of which have been previously demonstrated to be effective in Vitis. In this protocol, shoot tips (1-1.5 mm) were excised from micro-cuttings grown on pretreatment medium containing $0.2 \mathrm{mg} \mathrm{L}^{1}$ BA, $1 \mathrm{mM} \mathrm{SA}, 1 \mathrm{mM}$ GSH (reduced form), and $1 \mathrm{mM}$ AsA for 2-3 weeks. The shoot tips were then pre-cultured on $1 / 2 \mathrm{MS}$ medium containing $0.3 \mathrm{M}$ sucrose, $0.1 \mathrm{mM} \mathrm{SA}, 1 \mathrm{mM}$ AsA, and $1 \mathrm{mM} \mathrm{GSH}$ (reduced form) for 3 days at $25^{\circ} \mathrm{C}$ in the dark. The precultured shoot tips were treated with LS ( $2 \mathrm{M}$ glycerol $+0.4 \mathrm{M}$ sucrose in MS medium) for $20 \mathrm{~min}$ at $22^{\circ} \mathrm{C}$, followed by half-strength PVS2 for $30 \mathrm{~min}$ at $22{ }^{\circ} \mathrm{C}$ and full-strength PVS2 for $90 \mathrm{~min}$ at $0{ }^{\circ} \mathrm{C}$. The PVS2-treated shoot tips were placed onto a thin layer of PVS2 on foil strips and plunged into LN. The cryopreserved shoot tips were warmed in ULS (1.2 M sucrose in MS medium) for $20 \mathrm{~min}$ at $22^{\circ} \mathrm{C}$, and placed in recovery medium \#1 (1/2 MS macroelements without ammonium, full-strength MS microelements, and Vitis vitamins $\left(100 \mathrm{mg} \cdot \mathrm{L}^{-1}\right.$ myo inositol, $10 \mathrm{mg} \cdot \mathrm{L}^{-1}$ thiamine $\mathrm{HCl}, 1 \mathrm{mg} \cdot \mathrm{L}^{-1}$ nicotinic acid, $1 \mathrm{mg} \cdot \mathrm{L}^{-1}$ pyridoxine $\mathrm{HCl}$, $1 \mathrm{mg} \cdot \mathrm{L}^{-1}$ Ca pantothenate, $0.01 \mathrm{mg} \cdot \mathrm{L}^{-1}$ biotin, and $2 \mathrm{mg} \cdot \mathrm{L}^{-1}$ glycine) supplemented with $0.6 \mathrm{M}$ sucrose and $8 \mathrm{~g} \cdot \mathrm{L}^{-1}$ agar) overnight in the dark, and then transferred to recovery medium \#2 (1/2 MS macroelements without ammonium, full-strength MS microelements, and Vitis vitamins supplemented with $30 \mathrm{~g} \cdot \mathrm{L}^{-1}$ sucrose, $0.2 \mathrm{mg} \cdot \mathrm{L}^{-1} \mathrm{BA}$, and $8 \mathrm{~g} \cdot \mathrm{L}^{-1}$ agar) and cultured for 2 weeks at $25^{\circ} \mathrm{C}$ in darkness. The shoot tips were then transferred to recovery medium \#3 ( $1 / 2$ MS macroelements, full-strength MS microelements, and Vitis vitamins supplemented with $30 \mathrm{~g} \cdot \mathrm{L}^{-1}$ sucrose, $0.2 \mathrm{mg} \cdot \mathrm{L}^{-1} \mathrm{BA}$, and $8 \mathrm{~g} \cdot \mathrm{L}^{-1}$ agar) and grown in the light at $25^{\circ} \mathrm{C}$. The improvements in regrowth were achieved by eliminating ammonium from the recovery medium (\#1 and \#2) during the first 15 days of post-thaw incubation, minimizing the BA concentration in the recovery medium, increasing the agar concentration, and using a plastic sealing film (PVC) that increased the air exchange of cultures. With this optimized protocol, the shoot tip regrowth levels ranged from 24 to $43 \%$ and averaged at $35 \%$ across nine Vitis species.

Bettoni et al. [37] successfully repeated a similar protocol, proposed by Volk et al. [36], in 13 genotypes, representing 12 Vitis species (Table 1). The regrowth levels of least $43 \%$ and the successful replication by two technicians suggest that this method is ready for implementation. The same team demonstrated that Vitis shoot tips might be cryopreserved without introducing the accession into the tissue culture first [102,103]. In their study, nodal sections were harvested from plants grown in a growth chamber, surface sterilized $(70 \%$ isopropanol for $1 \mathrm{~min}$, followed by $5 \%$ sodium hypochlorite and $0.1 \%$ Tween 20 for $5 \mathrm{~min}$ ) and plated on pretreatment medium for 2 weeks, after which uniform shoot tips $(1 \mathrm{~mm})$ were dissected and pre-cultured for 3 days. The pretreatment and preculture media were those described above by Volk et al. [36], with addition of the $1.5 \%(v / v)$ plant preservation mixture $\left(\mathrm{PPM}^{\circledR}\right)$ to reduce microbial contamination. The precultured shoot tips were treated with LS for $20 \mathrm{~min}$, followed by two-step vitrification on PVS2 (half-strength PVS2 for $30 \mathrm{~min}$ at $22{ }^{\circ} \mathrm{C}$, followed by full-strength PVS2 for $30-40 \mathrm{~min}$ at $0{ }^{\circ} \mathrm{C}$ ) prior to immersion in LN. This method resulted in regrowth levels of 43-64\% for two $V$. vinifera cvs. Chardonnay and Riesling, and rootstock 'Oppenheim' (SO4; V. berlandieri $\times$ V. riparia) [102]. The rootstock 'Oppenheim' has a similar genetic background to 'Kober 5BB' (V. berlandieri $\times$ V. riparia), which was previously shown, by Fabbri et al. [92] and Ganino et al. [94], to be recalcitrant to cryopreservation using a one-step vitrification protocol. Using the protocol proposed by Bettoni et al. [102], 'Oppenheim' had a regrowth percentage of $48 \%$ 
after cryoexposure. The use of explants directly from the greenhouse, or possibly even from field-grown plants, could further increase the efficiency of cryopreserving cultivars in genebank collections; this needs to be explored for additional Vitis accessions.

\subsection{Cryo-Plate}

A vitrification protocol using the aluminum cryo-plate method ( $\mathrm{V}$ cryo-plate) was recently developed by Yamamoto et al. [147], using 'Dalmatian' chrysanthemum (Tanacetum cinerariifolium) in vitro shoot tips. The $\mathrm{V}$ cryo-plate method uses calcium alginate to attach shoot tips to cryo-plates. The shoot tips are then osmoprotected, PVS2-dehydrated, and immersed directly in LN [148]. Cryo-plate methods simplify the handling of shoot tips at different stages of cryopreservation [46]. The shoot tips remain attached to the cryo-plates throughout the whole procedure; therefore, they are easily transferred between solutions, allowing precise control of the treatment exposure duration, and reducing the risk of mechanical injury through handling during the course of the cryopreservation protocol. Fast cooling and warming rates have been reported to result in high regrowth levels after cryopreservation for a diverse range of genetic resources [76,147-151].

Bettoni et al. [76] were the first to report a V cryo-plate protocol for Vitis shoot tip cryopreservation. This protocol incorporates optimized pretreatment and preculture media, as well as the shoot tip recovery process using a droplet-vitrification cryopreservation method previously reported [36,37]. In this protocol, micro-cuttings were grown on pretreatment medium for 2 weeks, and then shoot tips $(1 \mathrm{~mm})$ were excised and placed on preculture medium for 3 days at $25^{\circ} \mathrm{C}$ in the dark. Droplets $(\sim 2 \mu \mathrm{L})$ of $2 \%$ sodium alginate solution, in a calcium-free MS basal medium supplemented with $0.4 \mathrm{M}$ sucrose, were placed into each well in the cryo-plates (No. 2; $37 \times 7 \times 0.5 \mathrm{~mm}$ ). Precultured shoot tips $(1 \mathrm{~mm})$ were placed individually into each well, and $1.5 \mu \mathrm{L}$ of sodium alginate solution was added to cover the shoot tips completely. Then, calcium chloride solution ( $0.1 \mathrm{M}$ calcium chloride in MS basal medium supplemented with $0.4 \mathrm{M}$ sucrose) was added dropwise to the cryo-plate, until all the wells were covered, and kept at $22{ }^{\circ} \mathrm{C}$ for $20 \mathrm{~min}$ for polymerization. Cryo-plates with shoot tips (Figure 2(D1)) were placed in LS (2 M glycerol + 0.4 M sucrose in MS medium) for $30 \mathrm{~min}$ at $22{ }^{\circ} \mathrm{C}$, followed by one-step vitrification on PVS2 for 30-40 min at $22{ }^{\circ} \mathrm{C}$ (Figure 2(D2)), prior to immersion in LN (Figure 2E). Cryo-plates with shoot tips were warmed in ULS (1.2 M sucrose in MS medium) at $22{ }^{\circ} \mathrm{C}$ for $20 \mathrm{~min}$, and alginate beads were then detached from the cryo-plates and transferred into the recovery medium. This protocol resulted in $68-70 \%$ shoot tip regrowth in the Vitis accessions V. aestivalis and V. jacquemontii. Given that this protocol can be easily executed, and high-quality plants were obtained from cryo-exposed shoot tips, it seems to be a practical and promising Vitis cryopreservation methodology. However, further work is required to determine the applicability of this protocol to a wider range of Vitis accessions.

\section{Shoot Tip Cryotherapy}

Shoot tip cryotherapy refers to freezing the infected shoot tips in LN to eradicate pathogens [52,55,152]. In 1997, Brison et al. [54] reported the first successful eradication of Plum pox virus (PPV) from the infected shoot tips of a Prunus rootstock, using a vitrification method. Since then, shoot tip cryotherapy has been successfully applied to eradicate 37 viruses [52,153-162], two viroids [163], two phytoplasmas [164,165], and one bacterium [166] in 31 plant species. To date, five phloem-limited grape viruses have been eradicated by shoot tip cryotherapy, including Grapevine fanleaf virus (GFLV), Grape virus A (GVA), Grapevine leafroll-associated virus-1,-2,-3 (GLRaV-1,2,3) [34,51,62-64,167] (Table 2). 
Table 2. Shoot tip cryotherapy for eradication of grapevine (Vitis spp.) viruses.

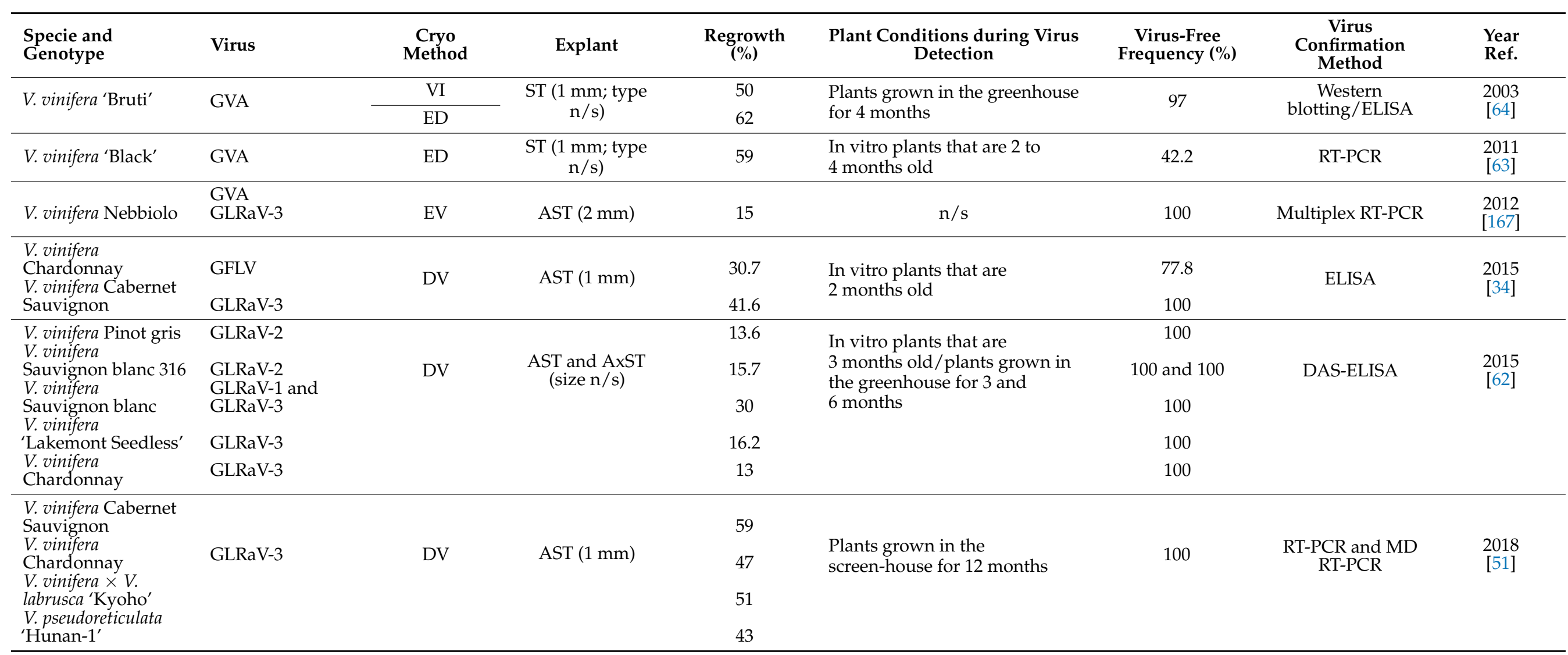

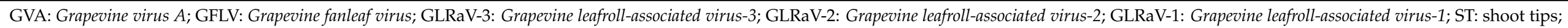

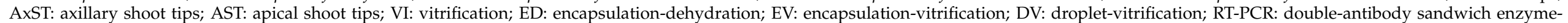

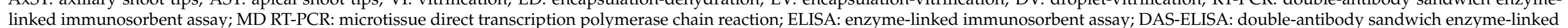
immunosorbent assay; $\mathrm{n} / \mathrm{s}$ : not specified. 


\subsection{Methods for Shoot Tip Cryotherapy}

Wang et al. [64] were the first to report the eradication of GVA from $V$. vinifera 'Bruti' using vitrification and encapsulation-dehydration cryotherapy. Vitrification and encapsulation-dehydration methods both resulted in $97 \%$ virus elimination, analyzed by Western blotting. Applying encapsulation-dehydration cryotherapy, Bayati et al. [63] obtained $42.3 \%$ GVA-free plants of $V$. vinifera 'Black', analyzed by reverse transcription polymerase chain reaction (RT-PCR). Gribaudo et al. [167] applied encapsulation-vitrification to eradicate GVA and GLRaV-3, and obtained $100 \%$ virus-free plants in V. vinifera Nebbiolo, analyzed by multiplex RT-PCR.

Pathirana et al. [62] used droplet-vitrification cryotherapy to eradicate GLRa-V-3, -2, and -1 from several $V$. vinifera cultivars, obtaining $100 \%$ GLRaV-3-free plants in $V$. vinifera Chardonnay and 'Lakemont Seedless', 100\% GLRaV-2-free plants in Pinot gris and 'Sauvignon blanc 316', and 100\% GLRaV-1-free and GLRaV-3-free plants in Sauvignon blanc, with an average shoot regrowth level of $17.7 \%$ across the cultivars. The virus eradication frequency was confirmed by double-antibody sandwich enzyme-linked immunosorbent assay (DAS-ELISA). Marković et al. [34] reported the successful eradication of GFLV from $V$. vinifera Chardonnay, and GLRaV-3 from V. vinifera Cabernet Sauvignon using droplet-vitrification, obtaining $100 \%$ and $77.8 \%$ virus-free frequencies, respectively, and a 57\% average regrowth level for the two cultivars [34]. Recently, Bi et al. [51] reported that all plants regenerated from cryopreservation were free of GLRaV-3, as confirmed by RT-PCR and microtissue direct RT-PCR (MD RT-PCR), in V. vinifera Cabernet Sauvignon and Chardonnay, $V$. vinifera $\times V$. labrusca 'Kyoho', V. pseudoreticulata 'Hunan- ${ }^{\prime}$ ', by droplet-vitrification. This report supported the critical role of LN exposure for successful cryotherapy for virus eradication [51].

Testing the effects of various steps of encapsulation-dehydration cryotherapy on virus eradication, Wang et al. [64] found that only the regenerants that recovered after LN exposure produced virus-free plants; the steps before and after freezing in LN failed to eradicate the virus. Virus eradication by freezing in LN, but not by other steps, during cryopreservation procedures was confirmed in droplet-vitrification $[51,62]$ and encapsulationdehydration [63]. Interestingly, Marković et al. [34] found that $100 \%$ and $82.4 \%$ of the plants of V. vinifera Cabernet Sauvignon and Chardonnay that recovered from PVS2 treatments without freezing in LN were free of GLRaV-3 and GFLV, respectively, which is very similar to the $100 \%$ and $77.8 \%$ virus-free plants recovered after cryopreservation. These results were in contrast with the former reports [62-64]. More studies are needed to verify if PVS treatments can eradicate viruses on other grape-virus combinations.

\subsection{Mechanism Involved in Shoot Tip Cryotherapy for Eradication of Phloem-Limited Grapevine Viruses}

The virus is unevenly distributed in the virus-infected shoot tips [55,59,160,161,168]. Immunohistochemical (IHC) observations found that phloem-limited GLRaV-3 was not present in the top-layer cells of the apical dome (AD) and the youngest four leaf primordia (LPs), but was present in the lower parts of the AD, LP 5, and older tissues of the virus-infected shoot tips of V. vinifera Cabernet Sauvignon, leaving about $0.5 \mathrm{~mm}$ of the meristematic area free of virus infection [51]. After freezing in LN, living cells were found in the top tissue of the AD and LPs 1-4 of the shoot tips (Figure 3). Few living cells were found in LP 5, and other cells were killed. Thus, plants that recover from cryotherapy can be free of viruses. The results of virus localization and cell surviving pattern provided explanations as to why shoot tip cryotherapy can eradicate phloem-limited grapevine viruses, such as GVA, GFLV, GLRa-V-3, -2, and -1 . 

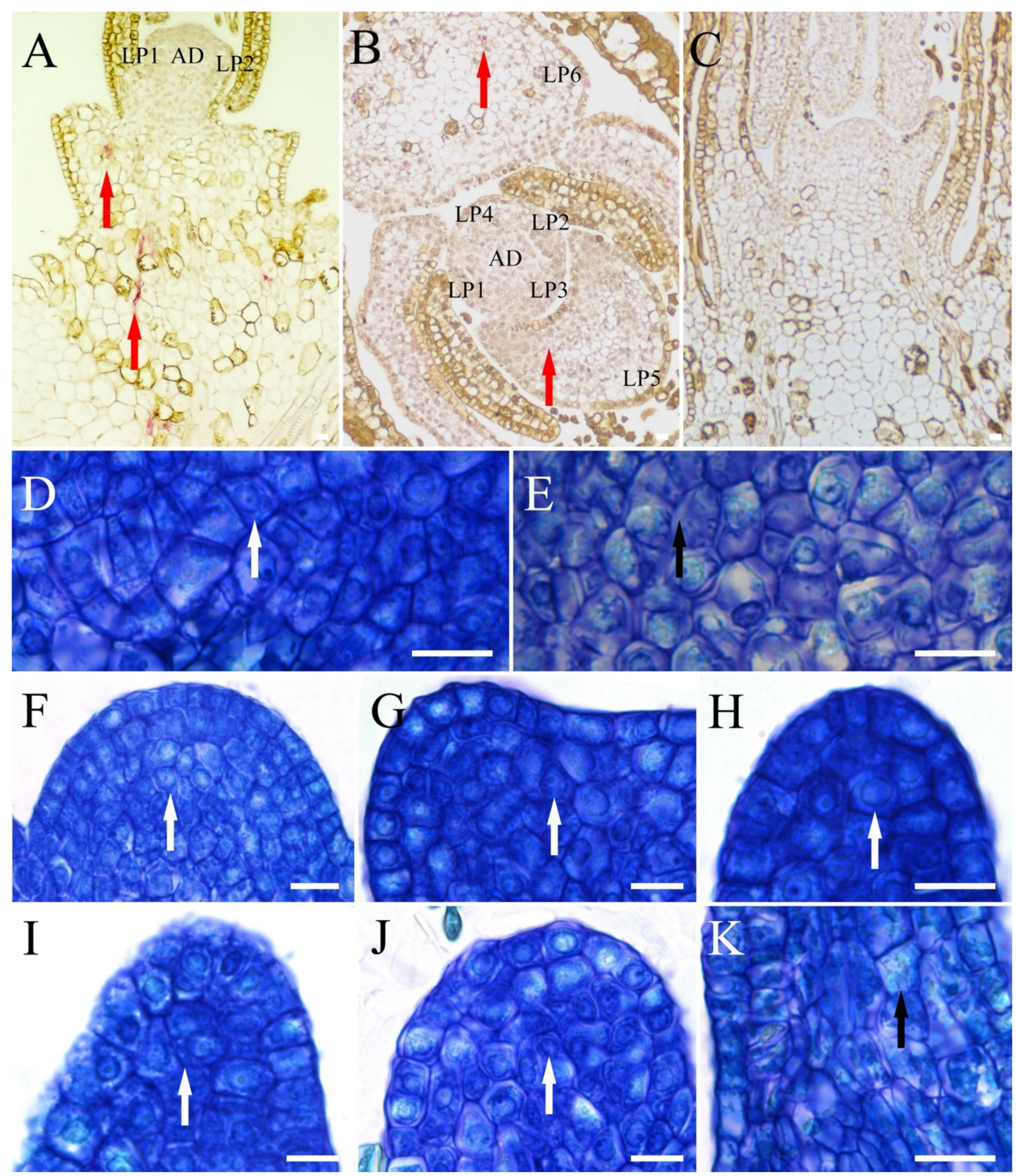

Figure 3. Immunohistological localization of Grapevine leafroll-associated virus-3 (GLRaV-3) in longitudinal section and cross section of shoot tips and histological observations of cell survival patterns in longitudinal sections of shoot tips following cryotherapy in grapevine cultivar Cabernet Sauvignon. Virus-infected cells are indicated by purple color (red arrows) reactions in $(\mathbf{A}, \mathbf{B})$, whereas no purple color reactions were spot in virus-free cells in (C). Surviving cells are densely stained with intact nucleus and nucleolus enclosed in a well-preserved cytoplasm (white arrows) in (D) as a positive control, dead cells are cytoplasm condensed with fractured plasma membrane (black arrows) in (E) as a negative control. Surviving cells in AD (F), and LP $1(\mathbf{G})$, LP $2(\mathbf{H})$, LP $3(\mathbf{I})$, LP $4(\mathbf{J})$ and dead cells in LP 5 (K) following cryotherapy are indicated by white arrows and black arrows. Bars $=10 \mu \mathrm{m}$. Source: Bi et al. [51]. 


\subsection{Comparison of Virus Eradication Efficiency between the Traditional Methods and Shoot Tip Cryotherapy}

Shoot tip culture (also called meristem culture) has traditionally been used to produce virus-free plants [93,169-174]. In shoot tip culture, the size of the shoot tips is positively related to survival and shoot regeneration, but negatively proportional to the virus eradication frequency. Therefore, typically, shoot tips of 0.1 to $0.5 \mathrm{~mm}$, containing an $\mathrm{AD}$ and $2-4$ LPs, are used for virus eradication $[64,93,173,174]$. The excision of such small shoot tips is difficult and requires skilled lab workers, in comparison to the larger shoot tips $(1.0 \mathrm{~mm})$ used in shoot tip cryotherapy (Table 2). It can also be difficult to regenerate plants from tiny shoot tips using traditional shoot tip culture methods [29,52,64,175]. Wang et al. [64] demonstrated that 0.5 to $2.0 \mathrm{~mm}$ shoot tips had similar high GVA-free frequencies (97\%) by using encapsulation-dehydration cryotherapy, with a $50 \%$ to $65 \%$ regrowth rate, while 0.2 to $0.4 \mathrm{~mm}$ shoot tips could only produce a maximum of $12 \%$ GVA-free frequencies by shoot tip culture, with a $75 \%$ to $100 \%$ regrowth rate. Although shoot tip cryotherapy produced lower shoot regrowth than meristem culture, shoot tip cryotherapy produced much higher virus eradication frequencies than the traditional methods. A shoot tip culture with 0.2 to $0.5 \mathrm{~mm}$ shoot tips has been used to obtain plants of rootstock Kalecik Karasi that were $100 \%$ free of GLRaV-3 [174], while, in cryotherapy, shoot tips of bigger size (1.0 to $2.0 \mathrm{~mm}$ ) were used to fully eradicate GLRaV-3 from grapevine Cabernet Sauvignon, Chardonnay, Nebbiolo, 'Kyoho', and rootstock 'Hunan-1' [34,51,167]. Those studies demonstrated that larger shoot tips could be used in shoot tip cryotherapy for efficient virus eradication, compared to the traditional methods.

Shoot tip culture is more effective in eliminating viruses when it is combined with thermotherapy $[175,176]$, and allows the use of larger shoot tips than those used for shoot tip culture without thermotherapy. Thermotherapy treatment associated with shoot tip culture resulted in virus-free frequencies of $91 \%$ for GLRaV- 1 and $68 \%$ for grapevine Rupestris stem pitting-associated virus (GRSPaV) in V. vinifera cv. Agiorgitiko [176], and $100 \%$ eradication for GFLV, $70 \%$ for GVA, $25 \%$ for GLRaV-1, 25\% for GLRaV-3, and $0 \%$ for Grapevine fleck virus (GFKV) in rootstock 'Kober 5BB' [177]. However, thermotherapy requires a temperature-controlled growth chamber, which is expensive. In addition, thermotherapy is time consuming compared with shoot tip culture.

In shoot tip cryotherapy, the success in eradicating viruses is independent of the size of the shoot tips used [64,160]. Wang et al. [64] tested the effect of shoot tip size (0.5 to $2.0 \mathrm{~mm})$ on survival and GVA eradication frequency after cryotherapy. Their study demonstrated that the size of the shoot tips affected the survival after cryopreservation. Shoot tips that were $1.0 \mathrm{~mm}$ had the highest survival, at $65 \%$, while greater or smaller sizes of shoot tips resulted in lower survival. However, the virus eradication frequency was not affected by the size of shoot tips used after cryopreservation, and was at a high level of $97 \%$ free of GVA. In the experiments of Bi et al. [51], three sizes of apical shoot tips were used to test regeneration and virus eradication efficiency by droplet-vitrification. Significantly higher survival $(75 \%)$ and regrowth $(59 \%)$ levels were obtained in the $1.0 \mathrm{~mm}$ shoot tip after cryopreservation. All the plants that recovered from LN were 100\% free from GLRaV-3, regardless of the size of shoot tips used. These reports are consistent with the findings obtained in virus eradication by cryotherapy so far $[55,59,64,160]$, confirming, again, that pathogen-free frequencies are independent of the size of shoot tips used for cryotherapy.

Relative to shoot tip culture or thermotherapy followed by shoot tip culture, shoot tip cryotherapy has the following advantages: cryotherapy yields pathogen-free plants at a high frequency; avoids the time-consuming excision of very small tissues, which requires skillful technicians; does require special equipment in addition to that typically available in a plant tissue culture laboratory. In summary, cryotherapy facilitates the treatment of a large number of samples quickly and simultaneously, reducing costs and making procedures shorter compared to thermotherapy followed by shoot tip culture $[52,54,64,81,152-155,175,178]$. 


\section{Conclusions and Future Prospects}

The availability of and easy access to Vitis genetic resources are essential for future breeding program advances. Shoot tip cryopreservation is a valuable technique for the safe, long-term conservation of Vitis genetic resources that complements traditional field and in vitro germplasm collection activity.

Reliable cryopreservation methods that result in high levels of regrowth are crucial to develop and implement backup collections in LN. Therefore, it is critical to ensure that the Vitis accessions being cryopreserved successfully recover normal plants. To avoid the production of somaclonal variants, it is important to recover shoot tips directly, without a callus intermediate [45].

Shoot tip cryopreservation protocols depend on tissue culture to regenerate healthy plants. Therefore, efficient cryopreservation protocols should include optimized micropropagation systems. Culture media formulation and growth conditions must be established to induce favorable physiological conditions for shoot tip donor plants, as well as appropriate conditions for shoot tip recovery post cryopreservation.

The success of cryopreservation protocols depends on a combination of numerous factors, such as shoot tip quality, pretreatment and preculture conditions, osmoprotection and vitrification dehydration steps, as well as the recovery process after cryoexposure, and these aspects can be genotype as well as species specific. One of the main factors to ensure success in Vitis cryopreservation is to obtain uniform, actively growing shoot tips. This can be achieved by growing micro-cuttings on pretreatment media containing cytokinin, antioxidants, and elicitors of defense proteins for 2-3 weeks, so one harvests relatively homogeneous $1 \mathrm{~mm}$ apical shoot tips. The addition of exogenous antioxidants and elicitors of defense proteins during preculturing helps improve the regrowth efficiency and quality of the plantlets of cryopreserved Vitis shoot tips [16,35-37,76,102].

Since the first report on grapevine shoot tip cryopreservation was published in 1989, much research has been carried out, with methods that been optimized to achieve post-thaw regrowth levels that satisfy the genebank standards for the implementation of cryopreserved Vitis collections. Reports on grapevine shoot tip cryopreservation using droplet-vitrification procedures that are applicable to a wide range of Vitis species [35-37] show promise for overcoming genotype-specific responses. Finally, the first effort to implement a cryopreserved Vitis collection has been initiated at USDA ARS National Laboratory for Genetic Resources Preservation, in Fort Collins, Colorado. At the present time, 28 Vitis accessions have been cryopreserved and stored within the cryotanks in LNV (Volk, personal communication).

Developing multiple cryopreservation methods for the successful preservation of a given plant species may help overcome genotype-specific responses; if one protocol fails, another may be successful for the same genotype within the species $[29,46]$. The $\mathrm{V}$ cryo-plate method uses shoot tips adhered to cryo-plates to facilitate manipulation, reduce mechanical injury from handling, and loss of shoot tips during the course of the cryopreservation protocol. This method follows the same principles as the droplet-vitrification method, by using ultra-fast shoot tip cooling and warming rates, an important requirement for successful cryopreservation protocols based on vitrification [147]. This method resulted in high regrowth levels, with high-quality plants obtained from cryo-exposed shoot tips, making it a practical and promising Vitis cryopreservation methodology [76]. Further work to determine the applicability of the $\mathrm{V}$ cryo-plate method across additional Vitis species would be advantageous.

Recent advances in Vitis cryopreservation research showed that shoot tips excised directly from plants that were not in tissue culture could be cryopreserved by dropletvitrification [102,103]. This would increase the efficiency of cryoprocessing in genebanks by significantly reducing the laborious steps of in vitro culture establishment and multiplication. The applicability of this protocol, using alternative sources of explants (particularly those originating from the field), to additional Vitis accessions needs to be determined.

Vitis is highly susceptible to virus infections. The availability of cryopreservation protocols developed for long-term Vitis preservation may also facilitate the use of cryotherapy 
methods in the production of virus-free plants. To date, studies on grapevine have shown the effectiveness of cryotherapy in the elimination of GVA, GFLV, GLRaV-1, GLRaV-2, and GLRaV-3.

This review provides comprehensive information on the development and recent progress of Vitis shoot tip cryopreservation and cryotherapy that resulted in healthy plants with high regrowth levels across diverse Vitis species. The next challenges for Vitis cryopreservation involve finding strategies to minimize labor inputs within cryo-banks, and to identify and prioritize collections to ensure the long-term security of Vitis genebank materials.

Author Contributions: Conceptualization, J.C.B., Z.M; data collection and analysis, preparation of the tables, writing—original draft preparation, J.C.B.; writing—review and editing, W.B., G.M.V., Q.-C.W.; preparation of the figures, G.M.V., W.B.; review and editing, Z.M., T.M. All authors have read and agreed to the published version of the manuscript.

Funding: This research received no external funding.

Institutional Review Board Statement: Not applicable.

Informed Consent Statement: Not applicable.

Acknowledgments: J.C.B. thanks Maree Debenham and Juliana Souza from Plant \& Food Research, Palmerston North, New Zealand, for providing internal review of the manuscript. Kathryn Chen from National Laboratory for Genetic Resources Preservation, Fort Collins of USA, provided drawn images shown in Figures 1 and 2. USDA is an equal opportunity employer.

Conflicts of Interest: The authors declare that they have no conflict of interest.

\section{Abbreviations}

$\begin{array}{ll}\text { AD } & \text { Apical dome } \\ \text { AsA } & \text { Ascorbic acid } \\ \text { AST } & \text { Apical shoot tips } \\ \text { AxST } & \text { Axillary shoot tips } \\ \text { BA } & \text { Benzylaminopurine } \\ \text { DAS-ELISA } & \text { Double-antibody sandwich enzyme-linked immunosorbent assay } \\ \text { DMSO } & \text { Dimethyl sulfoxide } \\ \text { ELISA } & \text { Enzyme-linked immunosorbent assay } \\ \text { FWB } & \text { Fresh weight basis } \\ \text { IHC } & \text { Immunohistochemical } \\ \text { LN } & \text { Liquid nitrogen } \\ \text { LNV } & \text { Liquid nitrogen vapor } \\ \text { LS } & \text { Loading solution } \\ \text { ULS } & \text { Unloading solution } \\ \text { SA } & \text { Salicylic acid } \\ \text { GVA } & \text { Grapevine virus A } \\ \text { GFKV } & \text { Grapevine fleck virus } \\ \text { GFLV } & \text { Grapevine fanleaf virus } \\ \text { GLRaV-1 } & \text { Grapevine leafroll-associated virus-1 } \\ \text { GLRaV-2 } & \text { Grapevine leafroll-associated virus-2 } \\ \text { GLRaV-3 } & \text { Grapevine leafroll-associated virus-3 } \\ \text { GSH } & \text { Glutathione } \\ \text { LP } & \text { Leaf primordia } \\ \text { MD RT-PCR } & \text { Microtissue direct reverse transcription polymerase chain reaction } \\ \text { MS } & \text { Murashige and Skoog (1962) medium } \\ \text { NAA } & \text { Naphthaleneacetic acid } \\ & \end{array}$




$\begin{array}{ll}\text { PPV } & \text { Plum pox virus } \\ \text { PVS } & \text { Plant vitrification solution } \\ \text { PVS2 } & \text { Plant vitrification solution 2 } \\ \text { PVS3 } & \text { Plant vitrification solution 3 } \\ \text { RT-PCR } & \text { Reverse transcription polymerase chain reaction } \\ \text { ROS } & \text { Reactive oxygen species } \\ \text { ST } & \text { Shoot tips } \\ \text { V cryo-plate } & \text { Vitrification cryo-plate } \\ \text { ZR } & \text { Zeatin riboside }\end{array}$

\section{References}

1. OIV (International Organisation of Vine and Wine). State of the World Vitivinicultural Sector in 2019; International Organisation of Vine and Wine: Paris, France, 2020. Available online: https://www.oiv.int/public/medias/7298/oiv-state-of-the-vitiviniculturalsector-in-2019.pdf (accessed on 5 July 2021).

2. This, P.; Lacombe, T.; Thomas, M.R. Historical origins and genetic diversity of wine grapes. Trends Genet. 2006, 22, 511-519. [CrossRef]

3. Gardiman, M.; Bavaresco, L. The Vitis germplasm repository at the CRA-VIT, Conegliano (Italy): Conservation, characterization and valorisation of grapevine genetic resources. Acta Hortic. 2015, 1082, 239-244. [CrossRef]

4. OIV (International Organisation of Vine and Wine). Focus OIV 2017: Distribution of the of the World's Grapevine Varieties; International Organisation of Vine and Wine: Paris, France, 2018. Available online: https://www.oiv.int/public/medias/5888/en-distributionof-the-worlds-grapevine-varieties.pdf (accessed on 5 July 2021).

5. Li, B.; Jiang, J.; Fan, X.; Zhang, Y.; Sun, H.; Zhang, G.; Liu, C. Molecular characterization of Chinese grape landraces (Vitis L.) using microsatellite DNA markers. HortScience 2017, 52, 533-540. [CrossRef]

6. Riaz, S.; Pap, D.; Uretsky, J.; Laucou, V.; Boursiquot, J.M.; Kocsis, L.; Walker, M.A. Genetic diversity and parentage analysis of grape rootstocks. App Genet. 2019, 132, 1847-1860. [CrossRef] [PubMed]

7. Smith, B.P.; Morales, N.B.; Thomas, M.R.; Smith, H.M.; Clingeleffer, P.R. Grapevine rootstocks resistant to the root-knot nematode Meloidogyne javanica. Aust. J. Grape Wine Res. 2017, 23, 125-131. [CrossRef]

8. Hou, H.; Li, H.; Wang, H.; Wang, X. Potential novel bZIP-like gene for resistance to Erysiphe necator identified in Chinese wild Vitis pseudoreticulata. Afr. J. Biotechnol. 2012, 11, 10926-10933. [CrossRef]

9. Sapkota, S.; Chen, L.L.; Yang, S.; Hyma, K.E.; Cadle-Davidson, L.; Hwang, C.F. Construction of a high-density linkage map and QTL detection of downy mildew resistance in Vitis aestivalis-derived 'Norton'. Appl. Genet. 2019, 132, 137-147. [CrossRef] [PubMed]

10. Blanc, S.; Wiedemann-Merdinoglu, S.; Dumas, V.; Mestre, P.; Merdinoglu, D. A reference genetic map of Muscadinia rotundifolia and identification of Ren5, a new major locus for resistance to grapevine powdery mildew. Appl. Genet. 2012, 125, 1663-1675. [CrossRef] [PubMed]

11. Myles, S. Improving fruit and wine: What does genomics have to offer? Trends Gen. 2013, 29, 190-196. [CrossRef]

12. Maia, J.D.G.; Carmargo, U.A.; Tonietto, J.; Zanus, M.C.; Quecini, V.; Ferreira, M.E.; Ritschel, P. Grapevine breeding programs in Brazil. In Grapevine Breeding Programs for the Wine Industry—Traditional and Molecular Techniques; Reynolds, A., Ed.; Woodhead Publishing: Sawston, UK, 2015; pp. 247-271. [CrossRef]

13. Postman, J.; Hummer, K.; Stover, E.; Krueger, R.; Forsline, P.; Grauke, L.J.; Zee, F.; Ayala-Silva, T.; Irish, B. Fruit and nut genebanks in the U.S. National Plant Germplasm System. HortScience 2006, 41, 1188-1194. [CrossRef]

14. Prins, B.; Volk, G.M.; Preece, J.E. Grape collection. In Field Tour of the USDA National Clonal Germplasm Repository for Tree Fruit, Nut Crops, and Grapes in Davis, California; Volk, G.M., Preece, J.E., Eds.; Colorado State University: Fort Collins, CO, USA, 2021. Available online: https:/ / colostate.pressbooks.pub/davisrepositoryfieldtour/chapter/grapes/ (accessed on 7 August 2021).

15. Elgelmann, F. In vitro conservation methods. In Biotechnology and Plant Genetic Resources; Callow, J.A., Ford-Lloye, B.V., Newbury, H.J., Eds.; CAB International: Wallingford, UK, 1997; pp. 119-161.

16. Pathirana, R.; McLachlan, A.; Hedderley, D.; Panis, B.; Carimi, F. Pre-treatment with salicylic acid improves plant regeneration after cryopreservation of grapevine (Vitis spp.) by droplet vitrification. Acta Physiol. Plant. 2016, 38, 12. [CrossRef]

17. Gisbert, C.; Peiró, R.; San Pedro, T.; Olmos, A.; Jiménez, C.; García, J. Recovering ancient grapevine varieties: From genetic variability to in vitro conservation, a case study. In Grapes and Wines-Advances in Production, Processing, Analysis and Valorization; Jordão, A.M., Cosme, F., Eds.; Intech: London, UK, 2018; pp. 3-21.

18. Silva, R.C.; Luis, Z.G.; Scherwinski-Pereira, J.E. Short-term storage in vitro and large-scale propagation of grapevine genotypes. Pesquisa Agropecuária Brasileira 2012, 47, 344-350. [CrossRef]

19. Hassanen, S.A.; Abido, A.I.A.; Aly, M.A.M.; Rayan, G.A. In vitro preservation of grapevine (Vitis vinifera L.) Muscat of Alexandria and Black Monukka cultivars as genetic resource. Afr. J. Basic Appl. Sci. 2013, 5, 55-63.

20. Hassan, N.A.; Stino, R.G.; Gomaa, A.H.; Al-Mousa, R.N. In vitro medium-term germplasm conservation and genetic stability of rape (Vitis vinifera L.). J. Hortic. Sci. Ornam. Plants 2014, 6, 9-17.

21. Barlass, M.; Skene, K.G.M. Long-term storage of grape in vitro. Plant. Genet. Resour. News 1983, 53, $19-21$. 
22. Panis, B.; Nagel, M.; Van den Houwe, I. Challenges and prospects for the conservation of crop genetic resources in field genebanks, in in vitro collection and/or in liquid nitrogen. Plants 2020, 9, 1634. [CrossRef]

23. Rodrigues, P.H.V.; Tulmann Neto, A.; Cassieri Neto, P.; Mendes, B.M.J. Influence of the number of subcultures on somaclonal variation in micropropagated Nanico (Musa spp., AAA group). Acta Hortic. 1998, 490, 469-473. [CrossRef]

24. Kulus, D.; Zalewska, M. Cryopreservation as a tool used in long-term storage of ornamental species-A review. Sci. Hortic. 2014, 168, 88-107. [CrossRef]

25. Höfer, M.; Hanke, M.V. Cryopreservation of fruit germplasm. In Vitro Cell. Dev. Biol.-Plant 2017, 53, 372-381. [CrossRef]

26. Dalla Costa, L.; Malnoy, M.; Lecourieux, D.; Deluc, L.; Ouaked-Lecourieux, F.; Thomas, M.R.; Torregrosa, L. The state-of-the-art of grapevine biotechnology and new breeding technologies (NBTS). OENO One 2019, 53, 205-228. [CrossRef]

27. Benson, E.E. Cryopreservation of phytodiversity: A critical appraisal of theory \& practice. Crit. Rev. Plant Sci. 2008, 27, 141-219. [CrossRef]

28. Harding, K. Genetic integrity of cryopreserved plant cells: A review. Cryo Lett. 2004, 25, 3-22.

29. Wang, M.R.; Chen, L.; Teixeira da Silva, J.A.; Volk, G.M.; Wang, Q.C. Cryobiotechnology of apple (Malus spp.): Development, progress and future prospects. Plant Cell Rep. 2018, 37, 689-709. [CrossRef]

30. Esensee, V.; Stushnoff, C. Cryoconservation of dormant grape (Vitis sp.) buds. In Proceedings of the 87th Annual Meeting of the American Society for Horticultural Science, Tucson, AZ, USA, 4-8 November 1990; Volume 25. Contributed Papers (Oral and Poster) Abstract \#190.

31. Matsumoto, T.; Sakai, A. Cryopreservation of in vitro-cultured axillary shoot tips of Vitis by vitrification. Acta Hortc. 2000, 538, 177-181. [CrossRef]

32. Matsumoto, T.; Sakai, A. Cryopreservation of axillary shoot tips of in vitro-grown grape (Vitis) by a two-step vitrification protocol. Euphytica 2003, 131, 299-304. [CrossRef]

33. Wang, Q.; Li, P.; Batuman, Ö.; Gafny, R.; Mawassi, M. Effect of benzyladenine on recovery of cryopreserved shoot tips of grapevine and citrus cultured in vitro. Cryo Lett. 2003, 24, 293-302. [PubMed]

34. Marković, Z.; Preiner, D.; Stupić, D.; Andabaka, Ž.; Šimon, S.; Vončina, D.; Maletić, E.; Karoglan Kontić, J.; Chatelet, P.; Engelmann, F. Cryopreservation and cryotherapy of grapevine (Vitis vinifera L.). Vitis 2015, 54, 247-251. [CrossRef]

35. Bi, W.L.; Hao, X.Y.; Cui, Z.H.; Volk, G.M.; Wang, Q. Droplet-vitrification cryopreservation of in vitro-grown shoot tips of grapevine (Vitis spp.). In Vitro Cell. Dev. Biol. -Plant 2018, 54, 590-599. [CrossRef]

36. Volk, G.M.; Shepherd, A.N.; Bonnart, R. Successful cryopreservation of Vitis shoot tips: Novel pre-treatment combinations applied to nine species. Cryo Lett. 2018, 39, 322-330. [PubMed]

37. Bettoni, J.; Kretzschmar, A.A.; Bonnart, R.; Shepherd, A.; Volk, G.M. Cryopreservation of 12 Vitis species using apical shoot tips derived from plants grown in vitro. HortScience 2019, 54, 976-981. [CrossRef]

38. Parfitt, D.E.; Almehdi, A.A. Cryogenic storage of grape pollen. Am. J. Enol. Vitic. 1983, 34, 227-228.

39. Ganeshan, S. Cryogenic preservation of grape, Vitis vinifera L., pollen. Vitis 1985, 173, 169-173.

40. Hassan, N.A.; Gomma, A.H.; Shahin, M.A.; El Homosany, A.A. In vitro storage and cryopreservation of some grape varieties. J. Hortc. Sci. Ornam. Plants 2013, 5, 183-193.

41. Wang, Q.; Mawassi, M.; Sahar, N.; Li, P.; Violeta, C.T.; Gafny, R.; Sela, I.; Tanne, E.; Perl, A. Cryopreservation of grapevine (Vitis spp.) embryogenic cell suspensions by encapsulation-vitrification. Plant Cell Tissue Organ. Cult. 2004, 77, 267-275. [CrossRef]

42. Wang, Q.C.; Gafny, R.; Sahar, N.; Sela, I.; Mawassi, M.; Tanne, E.; Perl, A. Cryopreservation of grapevine (Vitis vinifera L.) embryogenic cell suspensions and subsequent plant regeneration by encapsulation-dehydration. Plant Sci. 2002, 162, 551-558. [CrossRef]

43. Dussert, S.; Mauro, M.C.; Deloire, A.; Hamon, A.; Engelmann, F. Cryopreservation of grape embryogenic cell suspensions 1: Influence of pretreatment, freezing and thawing conditions. Cryo Lett. 1991, 12, 287-298.

44. Dussert, S.; Mauro, M.C.; Engelmann, F. Cryopreservation of grape embryogenic cell suspensions 2: Influence of post-culture conditions and application to different strains. Cryo Lett. 1992, 13, 15-22.

45. Carra, A.; Carimi, F.; Bettoni, J.C.; Pathirana, R. Progress and Challenges in the Application of Synthetic Seed Technology for Ex Situ Germplasm Conservation in Grapevine (Vitis spp.). In Synthetic Seeds; Faisal, A., Alatar, A.A., Eds.; Springer Nature: Cham, Switzerland, 2019; pp. 439-467. [CrossRef]

46. Bettoni, J.C.; Bonnart, R.; Volk, G.M. Challenges in implementing plant shoot tip cryopreservation technologies. Plant Cell Tissue Organ. Cult. 2021, 144, 21-34. [CrossRef]

47. Walters, C.; Richards, C.R.; Volk, G.M. Genebank conservation of germplasm collected from wild species. In North American Crop Wild Relatives, Volume 1; Greene, S.L., Williams, K.A., Khoury, C.K., Kantar, M.B., Marek, L.F., Eds.; Springer Nature: New York, NY, USA, 2018; pp. 245-280. [CrossRef]

48. Chofong, G.N.; Minarovits, J.; Richert-Pöggeler, K.R. Virus latency: Heterogeneity of host-virus interaction in shaping the virosphere. In Plant Virus-Host Interaction (Second Edition), Molecular Approaches and Viral Evolution; Gaur, R.K., Paul Khurana, S.M., Sharma, P., Hohn, T., Eds.; Academic Press: Cambridge, MA, USA, 2021; pp. 111-137. [CrossRef]

49. Hu, R.; Dias, N.P.; Soltani, N.; Vargas-Asencio, J.A.; Hensley, D.; Perry, K.L.; Domier, L.L.; Hajimorad, M.R. Cultivated and wild grapevines in Tennessee possess overlapping but distinct virus populations. Plant Dis. 2021. Online ahead of print. [CrossRef] 
50. Mannini, F.; Digiaro, M. The effects of viruses and viral diseases on grapes and wine. In Grapevine Viruses: Molecular Biology, Diagnostics and Management; Meng, B., Martelli, G., Golino, D., Fuchs, M., Eds.; Springer Nature: New York, NY, USA, 2017; pp. 453-482. [CrossRef]

51. Bi, W.L.; Hao, X.Y.; Cui, Z.H.; Pathirana, R.; Volk, G.M.; Wang, Q.C. Shoot tip cryotherapy for efficient eradication of grapevine leafroll-associated virus-3 from diseased grapevine in vitro plants. Ann. Appl. Biol. 2018, 173, 261-270. [CrossRef]

52. Bettoni, J.C.; Costa, M.D.; Gardin, J.P.P.; Kretzschmar, A.A.; Pathirana, R. Cryotherapy: A new technique to obtain grapevine plants free of viruses. Rev. Bras. Frutic. 2016, 38, e-833. [CrossRef]

53. Martelli, G.P.; Walter, B. Virus certification of grapevines. In Plant Virus Disease Control; Hadid, A., Khetarpal, R.K., Koganezawa, H., Eds.; APS Press: St Paul, MN, USA, 1998; pp. 150-166.

54. Brison, M.; Boucaud, M.T.; Pierronnet, A.; Dosba, F. Effect of cryopreservation on the sanitary state of a cv. Prunus rootstock experimentally contaminated with Plum Pox Potyvirus. Plant Sci. 1997, 123, 189-196. [CrossRef]

55. Wang, Q.C.; Valkonen, J.P.T. Cryotherapy of shoot tips: Novel pathogen eradication method. Trend Plant Sci. 2009, 14, 119-122. [CrossRef]

56. Helliot, B.; Panis, B.; Poumay, Y.; Swenen, R.; Lepoivre, P.; Frison, E. Cryopreservation for the elimination of cucumber mosaic and banana streak viruses from banana (Musa spp.). Plant Cell Rep. 2002, 20, 1117-1122. [CrossRef]

57. Yi, J.Y.; Lee, G.A.; Jeong, J.W.; Lee, S.Y.; Lee, Y.G. Eliminating Potato Virus Y (PVY) and Potato Leaf Roll Virus (PLRV) using cryotherapy of in vitro-grown potato shoot tips. Korean J. Crop. Sci. 2004, 59, 498-504. [CrossRef]

58. Wang, Q.; Liu, Y.; Xie, Y.; You, M. Cryotherapy of potato shoot tips for efficient elimination of Potato leaf roll virus (PLRV) and Potato virus Y (PVY). Potato Res. 2006, 49, 119-129. [CrossRef]

59. Wang, Q.C.; Valkonen, J.P.T. Elimination of two viruses which interact synergistically from sweetpotato by shoot tip culture and cryotherapy. J. Virol. Methods 2008, 154, 135-145. [CrossRef]

60. Bettoni, J.C.; Souza, J.A.; Volk, G.M.; Dalla Costa, M.; da Silva, F.N.; Kretzschmar, A.A. Eradication of latent viruses from apple cultivar 'Monalisa' shoot tips using droplet-vitrification cryotherapy. Sci. Hortic. 2019, 250, 12-18. [CrossRef]

61. Souza, J.A.; Bogo, A.; Bettoni, J.C.; Dalla Costa, M.; da Silva, F.N.; Casa, R.T.; Rufato, L. Droplet-vitrification cryotherapy for eradication of apple stem grooving virus and apple stem pitting virus from "Marubakaido" apple rootstock. Trop. Plant Pathol. 2020, 45, 148-152. [CrossRef]

62. Pathirana, R.; McLachlan, A.; Hedderley, D.; Carra, A.; Carimi, F.; Panis, B. Removal of leafroll viruses from infected grapevine plants by droplet-vitrification. Acta Hort. 2015, 1083, 491-498. [CrossRef]

63. Bayati, S.; Shams-Bakhsh, M.; Moieni, A. Elimination of Grapevine virus A (GVA) by cryotherapy and electrotherapy. J. Agric. Sci. Tech. 2011, 13, 443-450.

64. Wang, Q.; Mawassi, M.; Li, P.; Gafny, R.; Sela, I.; Tanne, E. Elimination of Grapevine virus A (GVA) by cryopreservation of in vitro-grown shoot tips of Vitis vinifera L. Plant Sci. 2003, 165, 321-327. [CrossRef]

65. Bi, W.L. Cryopreservation of Shoot Tips of Grapevine (Vitis spp.) and Cryotherapy for Eradication of grapevine Leafroll-Associated Virus 3. PhD Thesis, Northwest A\&F University, Yangling, Shaanxi, China, 2018.

66. Marković, Z. Cryopreservation and Cryotherapy of Grapevine (Vitis vinifera L.). PhD Thesis, University of Zagreb, Faculty of Agriculture Croatia, Zagreb, Croatia, 9 December 2013.

67. Bi, W.L.; Pan, C.; Hao, X.Y.; Cui, Z.H.; Kher, M.M.; Marković, Z.; Wang, Q.C.; Silva, J.A.T. Cryopreservation of grapevine (Vitis spp.)—A review. In Vitro Cell. Dev. Biol.-Plant 2017, 53, 449-460. [CrossRef]

68. Panis, B. Sixty years of plant cryopreservation: From freezing hardy mulberry twigs to establishing reference crop collections for future generations. Acta Hortic. 2019, 1234, 1-7. [CrossRef]

69. Agrawal, A.; Singh, S.; Malhotra, E.V.; Meena, D.P.S.; Tyagi, R.K. In vitro conservation and cryopreservation of clonally propagated horticultural species. In Conservation and Utilization of Horticultural Genetic Resources; Rajasekharan, P., Rao, V., Eds.; Springer Nature: New York, NY, USA, 2019; pp. 529-578. [CrossRef]

70. Malik, S.K.; Chaudhury, R. Cryopreservation techniques for conservation of tropical horticultural species using various explants. In Conservation and Utilization of Horticultural Genetic Resources; Rajasekharan, P., Rao, V., Eds.; Springer Nature: New York, NY, USA, 2019; pp. 579-594. [CrossRef]

71. Jenderek, M.M.; Reed, B.M. Cryopreserved storage of clonal germplasm in the USDA National plant germplasm system. In Vitro Cell. Dev. Biol.-Plant 2017, 53, 299-308. [CrossRef]

72. Keller, E.R.; Grübe, M.; Hajirezaei, M.R.; Melzer, M.; Mock, H.P.; Rolletschek, H.; Senula, A.; Subbarayan, K. Experience in large-scale cryopreservation and links to applied research for safe storage of plant germplasm. Acta Hortic. 2016, 1113, 239-249. [CrossRef]

73. Kim, H.H.; Popova, E.; Shin, D.J.; Yi, J.Y.; Kim, C.H.; Lee, J.S.; Yoon, M.K.; Engelmann, F. Cryobanking of Korean Allium germplasm collections: Results from a 10 year experience. Cryo Lett. 2012, 33, 45-57.

74. Vollmer, R.; Villagaray, R.; Cárdenas, J.; Castro, M.; Chávez, O.; Anglin, N.L.; Ellis, D. A large-scale viability assessment of the potato cryobank at the International Potato Centre (CIP). In Vitro Cell. Dev. Biol.-Plant 2017, 53, 309-317. [CrossRef]

75. Bettoni, J.C.; Bonnart, R.; Volk, G.M. Development of practical and successful Vitis shoot tip cryopreservation protocols. Cryobiology 2019, 91, 194-195. [CrossRef]

76. Bettoni, J.C.; Bonnart, R.; Shepherd, A.; Kretzschmar, A.A.; Volk, G.M. Modifications to a Vitis shoot tip cryopreservation procedure: Effect of shoot tip size and use of cryoplates. Cryo Lett. 2019, 40, 103-112. [PubMed] 
77. Engelmann., F. Use of biotechnologies for the conservation of plant biodiversity. In Vitro Cell. Dev. Biol.-Plant 2011, 47, 5-16. [CrossRef]

78. Wang, M.R.; Lambardi, M.; Engelmann, F.; Pathirana, R.; Panis, B.; Volk, G.M.; Wang, Q.C. Advances in cryopreservation of in vitro-derived propagules: Technologies and explant sources. Plant Cell Tissue Organ. Cult. 2021, 144, 7-20. [CrossRef]

79. Marković, Z.; Preiner, D.; Stupić, D.; Andabaka, Z.; Šikuten, I.; Kontić, J.K.; Maletić, E.; Štambuk, P. Cryopreservation Protocols for Grapevine Shoot Tips Cryopreservation. In Biotechnology in Biomedical and Biological Sciences; Bozkurt, Y., Ed.; IntechOpen Limited: London, UK, 2018; pp. 131-142. [CrossRef]

80. Takagi, H. Recent developments in cryopreservation of shoot tips of tropical species. In Cryopreservation of Tropical Plant Germplasm; Engelmann, F., Takagi, H., Eds.; International Plant Genetics Research Institute: Rome, Italy, 2000; pp. $178-193$.

81. Bettoni, J.C. Criopreservação: Uma ferramenta para conservação de recursos genéticos de videira. Agropecu. Catarin. 2019, 32, 92-97. [CrossRef]

82. Benelli, C.; De Carlo, A.; Engelmann, F. Recent advances in the cryopreservation of shoot-derived germplasm of economically important fruit trees of Actinidia, Diospyros, Malus, Olea, Prunus, Pyrus and Vitis. Biotechnol. Adv. 2013, 31, 175-185. [CrossRef] [PubMed]

83. Reed, B.M. Cryopreservation-Practical considerations. In Plant Cryopreservation: A Practical Guide; Reed, B.M., Ed.; Springer: New York, NY, USA, 2008; pp. 3-11. [CrossRef]

84. Ezawa, T.; Harada, T.; Yakuwa, T. Studies on freeze-preservation of fruit tree germplasm. III Freeze-preservation of grape shoot tips. J. Fac. Agric. Hokkaido Univ. 1989, 64, 51-55.

85. Plessis, P.; Leddet, C.; Dereuddre, J. Resistance to dehydration and to freezing in liquid nitrogen of alginate coated shoot tips of grapevine (Vitis vinifera L. cv. Chardonnay). Comptes Rendus l'Acad. Sci. Ser. 3 Sci. Vie 1991, 313, 373-380.

86. Plessis, P.; Leddet, C.; Collas, A.; Dereuddre, J. Cryopreservation of Vitis vinifera L. cv. Chardonnay shoot tips by encapsulation dehydration: Effects of pretreatment, cooling and postculture conditions. Cryo Lett. 1993, 14, 309-320.

87. Miaja, M.L.; Gribaudo, I.; Vallania, R.; Fernandez, L.F. Low temperature storage and cryopreservation of a Vitis vinifera L. germplasm collection: First results. Acta Hortic. 2000, 538, 177-181. [CrossRef]

88. Wang, Q.; Tanne, E.; Arav, A.; Gafny, R. Cryopreservation of in vitro-grow shoot tips of grapevine by encapsulation-dehydration. Plant Cell Tissue Organ. Cult. 2000, 63, 41-46. [CrossRef]

89. Zhao, C.; Wu, Y.; Engelmann, F.; Zhou, M. Cryopreservation of axillary buds of grape (Vitis vinifera) in vitro plantlets. Cryo Lett. 2001, 22, 321-328. [PubMed]

90. Benelli, C.; Lambardi, M.; Fabbri, A. Low Temperature Storage and Cryopreservation of the Grape Rootstock "Kober 5BB". Acta Hortic. 2003, 623, 249-253. [CrossRef]

91. Zhai, Z.; Wu, Y.; Engelmann, F.; Chen, R.; Zhao, Y. Genetic stability assessments of plantlets regenerated from cryopreserved in vitro cultured grape and kiwi shoot-tips using RAPD. Cryo Lett. 2003, 24, 315-322. [PubMed]

92. Fabbri, A.; Ganino, T.; Lombardi, M.; Nisi, R. Crioconservazione di gemme di portinnesto Kober 5BB (Vitis berlandieri x Vitis riparia): Aspetti anatomici. Italus Hortus 2007, 3, 82-86.

93. Shatnawi, M.; Anfoka, G.; Shibli, R.; Al-Mazra'Awi, M.; Shahrour, W.; Arebiat, A. Clonal propagation and cryogenic storage of virus-free grapevine (Vitis vinifera L.) via meristem culture. Turk. Agric. For. 2011, 35, 173-184. [CrossRef]

94. Ganino, T.; Silvanini, A.; Beghé, D.; Benelli, C.; Lambardi, M.; Fabbri, A. Anatomy and osmotic potential of the Vitis rootstock shoot tips recalcitrant to cryopreservation. Biol. Plant 2012, 56, 78-82. [CrossRef]

95. Marković, Z.; Chatelet, P.; Sylvestre, I.; Karoglan Kontić, J.; Engelmann, F. Cryopreservation of grapevine (Vitis vinifera L.) in vitro shoot tips. Cent. Eur. J. Biol. 2013, 8, 993-1000. [CrossRef]

96. Hassan, N.A.; Haggag, A.M. Cryopreservation of two Egyptian grape (Vitis vinifera) cultivars using two steps vitrification protocol. World Appl. Sci. J. 2013, 28, 254-258. [CrossRef]

97. Marković, Z.; Chatelet, P.; Preiner, D.; Sylvestre, I.; Karoglan Kontić, J.; Engelmann, F. Effect of shooting medium and source of material on grapevine (Vitis vinifera L.) shoot tip recovery after cryopreservation. Cryo Lett. 2014, 35, 40-47. [PubMed]

98. Lazo-Javelera, M.F.; Tiznado-Hernández, M.E.; Vargas-Arispuro, I.; Valenzuela-Soto, E.; Rocha-Granados, M.C.; MartínezMontero, M.E.; Rivera-Domínguez, M. Data on antioxidant activity in grapevine (Vitis vinifera L.) following cryopreservation by vitrification. Data Brief 2015, 5, 549-555. [CrossRef]

99. Dal Bosco, D.; Sinski, I.; Comachio, V.; Maia, J.D.G.; Ritschel, P.S.; Quecini, V. In vitro techniques for grapevine germplasm conservation. Acta Hortic. 2015, 1082, 201-205. [CrossRef]

100. Faltus, M.; Bilavčík, A.; Zámečník, J. Thermal analysis of grapevine shoot tips during dehydration and vitrification. Vitis 2015, $54,243-245$.

101. El-Homosany, A.; El-Wagab, A.; Samaan, M. Regeneration of some grape rootstock shoot tips after cryopreservation by dropletvitrification. Middle East. J. Agric. Res. 2019, 8, 1025-1030. [CrossRef]

102. Bettoni, J.C.; Bonnart, R.; Shepherd, A.; Kretzschmar, A.A.; Volk, G.M. Cryopreservation of grapevine (Vitis spp.) shoot tips from growth chamber-sourced plants and histological observations. Vitis 2019, 58, 71-78. [CrossRef]

103. Bettoni, J.C.; Bonnart, R.; Shepherd, A.; Kretzschmar, A.A.; Volk, G.M. Successful cryopreservation of Vitis vinifera 'Chardonnay' from both in vitro and growth chamber source plants. Acta Hortc. 2019, 1234, 211-218. [CrossRef]

104. AlMousa, R.N.; Hassan, N.A.F. Cryopreservation of grape (Vitis vinifera L.) using encapsulation-dehydration technique. J. Genet. Environ. Res. Conserv. 2021, 9, 153-156. 
105. Morel, G. Recherches sur la culture associée de parasites obligatoires et de tissus végétaux. Ann. Epiphyt. 1948, 14, 123-134.

106. Gamborg, O.L.; Miller, R.A.; Ojima, K. Nutrient requirements of suspension cultures of soybean root cells. Exp. Cell Res. 1968, 50, 151-158. [CrossRef]

107. Volk, G.M.; Shepherd, A.; Bonnart, R. Strategies for improved efficiency when implementing plant vitrification techniques. Acta Hortic. 2014, 1039, 85-89. [CrossRef]

108. Mathew, L.; McLachlan, A.; Jibran, R.; Burritt, D.J.; Pathirana, R. Cold, antioxidant and osmotic pre-treatments maintain the structural integrity of meristematic cells and improve plant regeneration in cryopreserved kiwifruit shoot tips. Protoplasma 2018, 255, 1065-1077. [CrossRef]

109. Panta, A.; Panis, B.; Ynouye, C.; Swennen, R.; Roca, W.; Tay, D.; Ellis, D. Improved cryopreservation method for the long-term conservation of the world potato germplasm collection. Plant Cell Tissue Organ. Cult. 2015, 120, 117-125. [CrossRef]

110. Kushnarenko, S.V.; Romadanova, N.V.; Reed, B.M. Cold acclimation improves regrowth of cryopreserved apple shoot tips. Cryo Lett. 2009, 30, 47-54. [PubMed]

111. Chang, Y.; Reed, B.M. Extended alternating-temperature cold acclimation and culture duration improve pear shoot cryopreservation. Cryobiology 2000, 40, 311-322. [CrossRef]

112. Reed, B.M. Antioxidants and cryopreservation, the new normal? Acta Hortic. 2014, 1039, 41-48. [CrossRef]

113. Wang, Q.; Laamanen, J.; Uosukainen, M.; Valkonen, J.P.T. Cryopreservation of in vitro-grown shoot tips of raspberry (Rubus idaeus L.) by encapsulation-vitrification and encapsulation-dehydration. Plant Cell Rep. 2005, 24, 280-288. [CrossRef]

114. Murashige, T.; Skoog, F. A revised medium for rapid growth and bioassays with tobacco tissue cultures. Physiol. Plant 1962, 15, 473-497. [CrossRef]

115. Charoensub, R.; Hirai, D.; Sakai, A. Cryopreservation of in vitro-grown shoot tips of cassava by encapsulation-vitrification method. Cryo Lett. 2004, 25, 51-58. [PubMed]

116. Halmagyi, A.; Deliu, C.; Coste, A. Plant regrowth from potato shoot tips cryopreserved by a combined vitrification-droplet method. Cryo Lett. 2005, 26, 313-322. [PubMed]

117. Bettoni, J.C. Cryopreservation for the Formation of Backup in Grapevine and Cryotherapy for Eradication of Virus from Apple Tree. PhD Thesis, Santa Catarina State University, Lages, Santa Catarina, Brazil, 6 September 2018. [CrossRef]

118. Uragami, A.; Sakai, A.; Nagai, M.; Takahashi, T. Survival of cultured cells and somatic embryos of Asparagus officinalis cryopreserved by vitrification. Plant Cell Rep. 1989, 8, 418-421. [CrossRef] [PubMed]

119. Sakai, A.; Kobayashi, S.; Oiyama, I. Cryopreservation of nucellar cells of navel orange (Citrus sinensis Osb. var. brasiliensis Tanaka) by vitrification. Plant Cell Rep. 1990, 9, 30-33. [CrossRef]

120. Fabre, L.; Dereuddre, J. Encapsulation-dehydration: A new approach to cryopreservation of Solanum shoot-tips. Cryo Lett. 1990, $11,413-426$.

121. Dereuddre, J.; Scottez, C.; Arnald, Y.; Doron, M. Resistance of alginate-coated axillary shoot tips of pear tree (Pyrus communis L. cv. Beurre Hardy) in vitro plantlets to dehydration and subsequent freezing in liquid nitrogen: Effects of previous cold hardening. Comptes Rendus l'Acad. Sci. Sér. III Sci. Vie 1990, 310, 317-323.

122. Engelmann, F. Plant cryopreservation: Progress and prospects. In Vitro Cell. Dev. Biol.-Plant 2004, 40, 427-433. [CrossRef]

123. Panis, B.; Lambardi, M. Status of cryopreservation technologies in plants (crops and forest trees). In Proceedings of the The Role of Biotechnology for the Characterization and Conservation of Crop, Forestry, Animal and Fishery Genetic Resources, Turin, Italy, 5-7 March 2005; pp. 43-54.

124. Nishizawa, S.; Sakai, A.; Amano, Y.; Matsuzawa, T. Cryopreservation of asparagus (Asparagus officinalis L.) embryogenic suspension cells and subsequent plant regeneration by vitrification. Plant Sci. 1993, 91, 67-73. [CrossRef]

125. Sakai, A.; Hirai, D.; Niino, T. Development of PVS-Based Vitrification and Encapsulation-Vitrification Protocols. In Plant Cryopreservation: A Practical Guide; Reed, B.M., Ed.; Springer: New York, NY, USA, 2008; pp. 33-57. [CrossRef]

126. Bettoni, J.C.; Pathirana, R.; Bonnart, R.; Shepherd, A.; Volk, G. Cryopreservation of grapevine shoot tips from in vitro plants using droplet vitrification and v cryo-plate techniques. In Synthetic Seeds; Faisal, A., Alatar, A.A., Eds.; Springer Nature: Cham, Switzerland, 2019; pp. 469-482. [CrossRef]

127. Bettoni, J.; Bonnart, R.M.; Volk, G.M. Vitis shoot tip cryopreservation (droplet vitrification and V-cryoplate). In Training in Plant. Genetic Resources: Cryopreservation of Clonal Propagules; Volk, G.M., Ed.; Colorado State University: Fort Collins, CO, USA, 2021. Available online: https:/ / colostate.pressbooks.pub/clonalcryopreservation/chapter/grapevine-shoot-tip-cryopreservationdroplet-vitrification-and-cryoplate/ (accessed on 7 August 2021).

128. Matsumoto, T.; Sakai, A. An approach to enhance dehydration tolerance of alginate-coated dried meristems cooled to $-196^{\circ} \mathrm{C}$. Cryo Lett. 1995, 16, 299-306.

129. Engelmann, F.; Arnao, M.T.G.; Wu, Y.; Escobar, R. Development of Encapsulation Dehydration. In Plant Cryopreservation: A Practical Guide; Reed, B.M., Ed.; Springer: New York, NY, USA, 2008; pp. 59-75. [CrossRef]

130. Sakai, A.; Engelmann, F. Vitrification, encapsulation-vitrification and droplet-vitrification: A review. Cryo Lett. 2007, $28,151-172$. [PubMed]

131. Volk, G.M.; Harris, J.L.; Rotindo, K.E. Survival of mint shoot tips after exposure to cryoprotectant solution components. Cryobiology 2006, 52, 305-308. [CrossRef]

132. Volk, G.M.; Maness, N.; Rotindo, K. Cryopreservation of garlic (Allium sativum L.) using plant vitrification solution 2. Cryo Lett. 2004, 25, 219-226. [PubMed] 
133. Matsumoto, T.; Sakai, A.; Yamada, K. Cryopreservation of in vitro-grown apical meristems of wasabi (Wasabia japonica) by vitrification and subsequent high plant regeneration. Plant Cell Rep. 1994, 13, 442-446. [CrossRef]

134. Engelmann, F. Importance of cryopreservation for the conservation of plant genetic resources. In Cryopreservation of Tropical Plant Germplasm; Engelmann, F., Takagi, H., Eds.; International Plant Genetics Research Institute: Rome, Italy, 2000; pp. 8-20.

135. Matsumoto, T.; Niino, T. The development of plant vitrification solution 2 and recent PVS2-based vitrification protocols. Acta Hortic. 2014, 1039, 21-28. [CrossRef]

136. Sakai, A. Plant cryopreservation. In Life in the Frozen State; Fuller, B., Lane, N., Benson, E.E., Eds.; CRC Press: Boca Raton, FL, USA, 2004; pp. 329-346.

137. Matsumoto, T.; Sakai, A.; Takahashi, C.; Yamada, K. Cryopreservation of in vitro-grown apical meristems of wasabi (Wasabia japonica) by encapsulation-vitrification method. Cryo Lett. 1995, 16, 189-196.

138. Kartha, K.K.; Leung, N.L.; Mroginski, L.A. In vitro growth-responses and plant-regeneration from cryopreserved meristems of cassava (Manihot esculenta Crantz). Z. Pflanzenphysiol. 1982, 107, 133-140. [CrossRef]

139. Schäfer-Menuhr, A.; Schumacher, H.M.; Mix-Wagner, G. Langzeitlagerung alter Kartoffelsorten durch Kryokonservierung der Meristeme. Landbauforsch. Völkenrode 1994, 44, 301-313. [CrossRef]

140. Schäfer-Menuhr, A.; Müller, E.; Mix-Wagner, G. Cryopreservation: An alternative for the long-term storage of old potato cultivars. Potato Res. 1996, 39, 507-513. [CrossRef]

141. Schäfer-Menuhr, A.; Schumacher, H.M.; Mix-Wagner, G. Cryopreservation of potato cultivars-design of a method for routine application in genebanks. Acta Hortic. 1997, 447, 447-482. [CrossRef]

142. Panis, B.; Piette, B.; Swennen, R. Droplet vitrification of apical meristems: A cryopreservation protocol applicable to all Musaceae. Plant Sci. 2005, 168, 45-55. [CrossRef]

143. Souza, F.V.; Kaya, E.; Vieira, L.J.; de Souza, E.H.; Amorim, V.B.O.; Skogerboe, D.; Matsumoto, T.; Alves, A.A.C.; Ledo, C.A.S.; Jenderek, M.M. Droplet-vitrification and morphohistological studies of cryopreserved shoot tips of cultivated and wild pineapple genotypes. Plant Cell Tissue Organ. Cult. 2016, 124, 351-360. [CrossRef]

144. Volk, G.M.; Walters, C. Preservation of Genetic Resources in the National Plant Germplasm Clonal Collections. Plant Breed. Rev. 2003, 23, 291-344. [CrossRef]

145. Niino, T.; Arizaga, M. Cryopreservation for preservation of potato genetic resources. Breed. Sci. 2015, 65, 41-52. [CrossRef]

146. Panis, B.; Piette, B.; André, E.; Van den Houwe, I.; Swennen, R. Droplet vitrification: The first generic cryopreservation protocol for organized plant tissues? Acta Hortic. 2011, 908, 157-163. [CrossRef]

147. Yamamoto, S.; Rafique, T.; Priyantha, W.S.; Fukui, K.; Matsumoto, T.; Niino, T. Development of a cryopreservation procedure using aluminium cryo-plates. Cryo Lett. 2011, 32, 256-265. [PubMed]

148. Matsumoto, T.; Niino, T. Manual of Cryopreservation Methods Using Cryo-Plate: V and D Cryo-Plate Procedure as an Effective Protocol for Cryobanks; Niino, T., Matsumoto, T., Yamamoto, S.-I., Maki, S., Tanata, D., Engelmann, F., Eds.; Plant Tissue Culture and Cryopreservation Group (PTCCcryoG): Tsukuba, Japan, 2017; pp. 8-15.

149. Matsumoto, T. Cryopreservation of plant genetic resources: Conventional and new methods. Rev. Agric. Sci. 2017, 5, 13-20. [CrossRef]

150. Niino, T.; Yamamoto, S.; Matsumoto, T.; Elgelmann, F.; Valle Arizaga, M.; Tanaka, D. Development of V and D cryo-plate methods as effective protocols for cryobanking. Acta Hortic. 2019, 1234, 249-262. [CrossRef]

151. Yamamoto, S.; Rafique, T.; Fukui, K.; Sekizawa, K.; Niino, T. V-cryoplate procedure as an effective protocol for cryobanks: Case study of mint cryopreservation. Cryo Lett. 2012, 33, 12-23. [PubMed]

152. Wang, Q.C.; Panis, B.; Engelmann, F.; Lambardi, M.; Valkonen, J.P.T. Cryotherapy of shoot tips: A technique for pathogen eradication to produce healthy planting materials and prepare healthy plant genetic resources for cryopreservation. Ann. Appl. Biol. 2009, 154, 351-363. [CrossRef]

153. Zhao, L.; Wang, M.R.; Li, J.W.; Cui, Z.H.; Volk, G.M.; Wang, Q.C. Cryobiotechnology: A double-edged sword for obligate plant pathogens. Plant Dis. 2019, 103, 1058-1067. [CrossRef] [PubMed]

154. Jiroutová, P.; Sedlák, J. Cryobiotechnology of plants: A hot topic not only for gene banks. Appl. Sci. 2020, 10, 4677. [CrossRef]

155. Bettoni, J.C.; Souza, J.A. Crioterapia: Uma potencial ferramenta para erradicação de vírus em plantas. Rev. Agron. Bras. 2018, 2, 1-3. [CrossRef]

156. Liu, X.X.; Mou, S.W.; Cheng, Z.H. Effect of cryopreservation on plant growth, bulb characteristics, and virus reduction of garlic (Allium Sativum L.). Cryo Lett. 2019, 40, 322-332. [PubMed]

157. Luo, Y.; Qiu, J.; Ling, Y.J.; Mo, Q.; Ran, X.R.F.; Tang, H.R. The application of cryotherapy in virus elimination of strawberry. Mol. Plant Breed. 2016, 14, 2488-2494.

158. Sheng, H.Y.; Wan, J.H.; Xu, C.; Wang, H.Q. Preliminary study on elimination of strawberry mottle virus (SMoV) from shoot tips by vitrification-cryopreservation treatment. J. China Agric. Univ. 2016, 21, 53-57.

159. Zeng, J.W.; Niu, W.C.; Huang, Y.H.; Sun, Z.H.; Huang, B.Z.; Yi, G.J.; Zhou, B.R. 2009. Elimination of Banana Bunchy Top Virus (BBTV) by cryopreservation of in vitro-grown shoot tips from Banana (Musa spp.). J. Plant Gene Res. 2009, 10, 457-460.

160. Li, B.Q.; Feng, C.H.; Hu, L.Y.; Wang, M.R.; Wang, Q.C. Shoot tip culture and cryopreservation for eradication of Apple stem pitting virus (ASPV) and Apple stem grooving virus (ASGV) from apple rootstocks 'M9' and 'M26'. Ann. Appl. Biol. 2016, 168, 142-150. [CrossRef] 
161. Zhao, L.; Wang, M.R.; Cui, Z.H.; Chen, L.; Volk, G.M.; Wang, Q.C. Combining thermotherapy with cryotherapy for efficient eradication of Apple stem grooving virus from infected in-vitro-cultured apple shoots. Plant Dis. 2018, 102, 1574-1580. [CrossRef] [PubMed]

162. Farhadi-Tooli, S.; Ghanbari, A.; Kermani, M.J.; Zeinalabedini, M.; Bettoni, J.C.; Naji, A.M.; Kazemi, N. Droplet-vitrification cryotherapy and thermotherapy as efficient tools for the eradication of apple chlorotic leaf spot virus and apple stem grooving virus from virus-infected quince in vitro cultures. Eur. J. Plant Pathol. 2021. [CrossRef]

163. Jeon, S.M.; Naing, A.H.; Kim, H.H.; Chung, M.Y.; Lim, K.B.; Kim, C.K. Elimination of chrysanthemum stunt viroid and chrysanthemum chlorotic mottle viroid from infected chrysanthemum by cryopreservation. Protoplasma 2016, 253, 1135-1144. [CrossRef] [PubMed]

164. Wang, R.R.; Mou, H.Q.; Gao, X.X.; Chen, L.; Li, M.F.; Wang, Q.C. Cryopreservation for eradication of Jujube witches' broom phytoplasma from Chinese jujube (Ziziphus jujuba). Ann. Appl. Biol. 2015, 166, 218-228. [CrossRef]

165. Wang, Q.C.; Valkonen, J.P.T. Efficient elimination of Sweetpotato little leaf phytoplasma from sweetpotato by cryotherapy of shoot tips. Plant Pathol. 2008, 57, 338-347. [CrossRef]

166. Ding, F.; Jin, S.X.; Hong, N.; Zhong, Y.; Cao, Q.; Yi, G.J.; Wang, G.P. Vitrification-cryopreservation, an efficient method for eliminating Candidatus Libero bacterasiaticus, the citrus Huanglongbing pathogen, from in vitro adult shoot tips. Plant Cell Rep. 2008, 27, 241-250. [CrossRef]

167. Gribaudo, I.; Cuozzo, D.; Ganbino, G.; Vallania, R. Applicazione della tecnica di incapsulazione-vitrificazione per la crioconservazione e la crioterapia in vite. Convegno Nazionale di Viticoltura 2012, 3, 372-374.

168. Kaya, E.; Galatali, S.; Güldağ, S.; Celik, O. A new perspective on cryotherapy: Pathogen elimination using plant shoot apical meristem via cryogenic techniques. In Plant Stem Cells, Methods in Molecular Biology; Naseem, M., Dandekar, T., Eds.; Humana: New York, NY, USA, 2000; pp. 137-148. [CrossRef]

169. Barlass, M.; Skene, K.G.M.; Woodham, R.C.; Krake, L.R. Regeneration of virus-free grapevines using in vitro apical culture. Ann. Appl. Biol. 1982, 101, 291-295. [CrossRef]

170. Youssef, S.A.; Al-Dhaher, M.M.A.; Shalaby, A.A. Elimination of grapevine fanleaf virus (GFLV) and grapevine leaf roll-associated virus-1 (GLRaV-1) from infected grapevine plants using meristem tip culture. Int. J. Virol. 2009, 5, 89-99. [CrossRef]

171. Fayek, M.A.; Jomaa, A.H.; Shalaby, A.B.A. Meristem tip culture for in vitro eradication of grapevine leaf roll-associated virus-1 (GLRaV-1) and grapevine fan leaf virus (GFLV) from infected flame seedless grapevine plantlets. Iniciación A La Investig. 2009, $4,1-11$.

172. Dĩaz-Barrita, A.J.; Norton, M.; Martĩnez-Peniche, R.A.; Uchanski, M.; Mulwa, R.; Skirvin, R.M. The use of thermotherapy and in vitro meristem culture to produce virus-free 'chancellor' grapevines. Int. J. Fruit Sci. 2008, 7, 15-25. [CrossRef]

173. Salami, S.A.; Ebadi, A.; Zamani, Z.; Habibi, M.K. Incidence of grapevine fanleaf virus in Iran: A survey study and production of virus-free material using meristem culture and thermotherapy. Eur. J. Hortic. Sci. 2009, 74, 42-46.

174. Celik, H.; Söylemezoglu, G.; Ertunc, F.; Cakir, A.; Dursunoglu, S.; Akbas, B. Clonal micropropagation of main grape and rootstock varieties of Turkish viticulture for obtaining virus-free basic nursery stocks. In Proceedings of the IX International Conference on Grape Genetics and Breeding, Verona, Italy, 13-18 June 2006; Volume 827, pp. 421-424.

175. Wang, M.R.; Cui, Z.H.; Li, J.W.; Hao, X.Y.; Zhao, L.; Wang, Q.C. In vitro thermotherapy-based methods for plant virus eradication. Plant Methods 2018, 14, 87. [CrossRef] [PubMed]

176. Skiada, F.G.; Grigoriadou, K.; Maliogka, V.I.; Katis, N.I.; Eleftheriou, E.P. Elimination of grapevine leafroll-associated virus 1 and grapevine rupestris pitting-associated virus from grapevine cv. Agiorgitiko and a micropropagation of protocol for mass production of virus-free plantlets. J. Plant Pathol. 2009, 91, 177-184. [CrossRef]

177. Panattoni, A.; Triolo, E. Susceptibility of grapevine viruses to thermotherapy on in vitro collection of Kober 5BB. Sci. Hortic. 2010, 125, 63-67. [CrossRef]

178. Wang, M.R.; Chen, L.; Zhang, Z.; Blystad, D.R.; Wang, Q.C. Cryotherapy: A novel method for virus eradication in economically important plant species. In Plant Cell Culture Protocols, Methods in Molecular Biology; Loyola-Vargas, V.M., Ochoa-Alejo, N., Eds.; Springer Nature: Cham, Switzerland, 2018; pp. 257-268. [CrossRef] 